\title{
Quantum chemical studies on the molecular structure, spectroscopic and electronic properties of (6-Methoxy-2-oxo-2H-chromen-4-yl)-methyl pyrrolidine-1-carbodithioate
}

\author{
Meryem Evecen, Hasan TANAK* \\ Department of Physics, Faculty of Arts and Sciences, Amasya University, 05000, Amasya, Turkey
}

\begin{abstract}
In this paper, the molecular geometry, vibrational frequencies and chemical shifts of (6-Methoxy-2-oxo-2H-chromen-4yl)methyl pyrrolidine-1-carbodithioate in the ground state have been calculated using the Hartree-Fock and density functional methods with the $6-311++\mathrm{G}(\mathrm{d}, \mathrm{p})$ basis set. To investigate the nonlinear optical properties of the title compound, the polarizability and the first hyperpolarizability were calculated. The conformational properties of the molecule have been determined by analyzing molecular energy properties. Using the time dependent density functional theory, electronic absorption spectra have been calculated. Frontier molecular orbitals, natural bond orbitals, natural atomic charges and thermodynamical parameters were also investigated by using the density functional theory calculations.
\end{abstract}

Keywords: coumarin; vibrational spectroscopy; density functional theory; chemical shifts; electronic properties

(C) Wroclaw University of Technology.

\section{Inroduction}

Coumarins are wide spread in nature, like flavonoids, which are also extensively represented in plants, and whose beneficial properties have only recently gained recognition [1]. They are structurally closely related to chromenes and show various biological activities [2-6]. Some coumarin derivatives, due to their outstanding optical properties, have also found a place and subsequent use in laser dyes, non-linear optical chromophores, fluorescent whiteners, fluorescent probes and solar energy collectors [7-10]. Because of its unique medicinal properties, structural variability, low cost and low toxicity, the coumarin scaffold has been broadly used in the design and development of a number of pharmaceutically important compounds [11]. Depending on the nature as well as pattern of the substitution, coumarins may display a variety of pharmacological, biochemical and therapeutic properties [12, 13].

\footnotetext{
*E-mail: hasantanak@gmail.com
}

By means of increasing development of computational chemistry in the past decade, the research of theoretical modeling of drug design, functional material design, etc., has become much more mature than ever. Many important chemical and physical properties of biological and chemical systems can be predicted from the first principles by various computational techniques [14]. In recent years, density functional theory (DFT) has been a shooting star in theoretical modeling. The development of better and better exchange-correlation functionals made it possible to calculate many molecular properties with comparable accuracies to traditional correlated ab-initio methods, at more favorable computational costs [15]. Literature survey revealed that the DFT has a great accuracy in reproducing the experimental values of geometry, vibrational frequency, electronic absorption spectra, etc. $[16,17]$.

In the previous publication, the X-ray crystallography and IR spectra of (6-Methoxy-2oxo-2H-chromen-4-yl)-methyl pyrrolidine-1carbodithioate were studied [18]. In spite of its 
importance, mentioned above, no theoretical calculation concerning (6-Methoxy-2-oxo-2H-chromen4-yl)-methyl pyrrolidine-1-carbodithioate has been published yet. The aim of this study is to investigate the spectral and structural properties of the coumarin compound, (6-Methoxy-2oxo-2H-chromen-4-yl)-methyl pyrrolidine-1carbodithioate, using the Hartree-Fock (HF) and density functional theory (DFT) calculations. In this work, the molecular structure, vibrational spectra and assignments, ${ }^{1} \mathrm{H}-$ and ${ }^{13} \mathrm{C}$ NMR spectra, electronic absorption spectra, frontier molecular orbitals (FMO), natural bond orbitals (NBO), natural atomic charges, nonlinear optical properties and thermodynamical parameters of (6-Methoxy-2-oxo-2H-chromen-4-yl)-methyl pyrrolidine-1-carbodithioate were investigated. These calculations are valuable for providing insight into molecular properties of coumarins.

\section{Theoretical methods}

The molecular geometry was taken directly from the X-ray diffraction experimental result without any constraints. The HF and DFT calculations of the compound have been done using the Gaussian 09W software [19]. The vibrational frequencies were calculated at the $\mathrm{HF}$ and DFT/B3LYP levels for the optimized structures and the predicted frequencies were scaled by 0.96 for DFT/B3LYP and 0.89 for HF. Vibrational band assignments were made using the Gauss-View 5 software [20]. Besides, the thermodynamic functions of the title compound at different temperatures were calculated on the basis of vibrational analysis, using B3LYP/6-311++G(d,p) level. To identify the conformational flexibility, two selected degrees of torsional freedom, T(S1-C18-N6-C19) and $\mathrm{T}(\mathrm{S} 1-\mathrm{C} 17-\mathrm{C} 14-\mathrm{C} 15)$, were changed from $-180^{\circ}$ to $+180^{\circ}$ in steps of $10^{\circ}$, and the molecular energy profiles were obtained at the DFT/B3LYP level. The ${ }^{1} \mathrm{H}-$ and ${ }^{13} \mathrm{C}-\mathrm{NMR}$ chemical shifts were calculated using the Gauge-Independent Atomic Orbital (GIAO) approach [21] applying B3LYP and HF methods with $6-311++\mathrm{G}(\mathrm{d}, \mathrm{p})$ basis set. The geometry of the compound, together with that of tetramethylsilane (TMS), was fully optimized.
The obtained ${ }^{1} \mathrm{H}-$ and ${ }^{13} \mathrm{C}-\mathrm{NMR}$ chemical shifts were derived from the equation $\delta=\Sigma_{0}-\Sigma$, where $\delta$ is the chemical shift, $\Sigma$ is the absolute shielding and $\Sigma_{0}$ is the absolute shielding of the standard (TMS) [22]. The solvent effect on the theoretical ${ }^{1} \mathrm{H}-$ and ${ }^{13} \mathrm{C}-\mathrm{NMR}$ parameters was included using the the integral equation formalism polarisable continuum model (IEF-PCM) [23] provided by Gaussian 09W. Ethanol and dimethylsulfoxide (DMSO) were used as solvents. The linear polarizability and first hyperpolarizability properties of the title compound were predicted by molecular polarizabilities basing on theoretical calculations. In addition, NBO and FMOs were performed at the B3LYP/6-311++G(d,p) level.

\section{Results and discussion}

\subsection{Optimized geometries}

The atomic numbering scheme for the title crystal [18] and the theoretical geometric structure of the title compound are shown in Fig. 1. The crystal structure of the title compound is triclinic and space group is $\mathrm{P}-1$. The crystal structure parameters are $\mathrm{a}=6.7223$ (2) $\AA, \mathrm{b}=8.0369$ (2) $\AA$, $\mathrm{c}=15.4101(5) \AA, \alpha=75.320(2)^{\circ}, \beta=88.482$ $(1)^{\circ}, \gamma=78.842(1)^{\circ}$ and $\mathrm{V}=789.93$ (4) $\AA^{3}$ [18].

The optimized bond lengths, bond angles and torsion angles of the title compound have been obtained using the HF and DFT/B3LYP methods with the $6-311++\mathrm{G}(\mathrm{d}, \mathrm{p})$ basis set. Theoretical and experimental geometric parameters are listed in Table 1. When the X-ray structure of the title compound is compared with its optimized counterparts (Fig. 2), slight conformational discrepancies are observed between them. The title crystal is not planar. The dihedral angle between the $2 \mathrm{H}$-chromene $(\mathrm{O} 4 / \mathrm{C} 8-\mathrm{C} 16)$ ring and pyrrolidine $(\mathrm{N} 6 / \mathrm{C} 18-\mathrm{C} 22)$ ring is $75.24(16)^{\circ}$ for $\mathrm{X}$-ray [18], whereas the dihedral angle has been calculated as $67.65^{\circ}$ for B3LYP and $70.00^{\circ}$ for HF. The orientation of the both the rings is defined by the torsion angles C22-N6-C18-S1 $\left(178.00^{\circ}\right)$, N6-C18-S1-C17 $\left(-170.98^{\circ}\right), \quad \mathrm{C} 18-\mathrm{S} 1-\mathrm{C} 17-\mathrm{C} 14 \quad\left(103.72^{\circ}\right)$ and S1-C17-C14-C15 $\left(-99.35^{\circ}\right)$ which have been calculated as $178.48^{\circ},-176.56^{\circ}, 105.99^{\circ}$ and $-104.04^{\circ}$ for $\mathrm{B} 3 \mathrm{LYP}$, and $178.56^{\circ},-174.45^{\circ}$, 
$98.78^{\circ}$ and $-107.40^{\circ}$ for $\mathrm{HF}$, respectively. In the title compound, the bond lengths and angles are within normal ranges and they are comparable with those of related compounds [24-26].

(a)
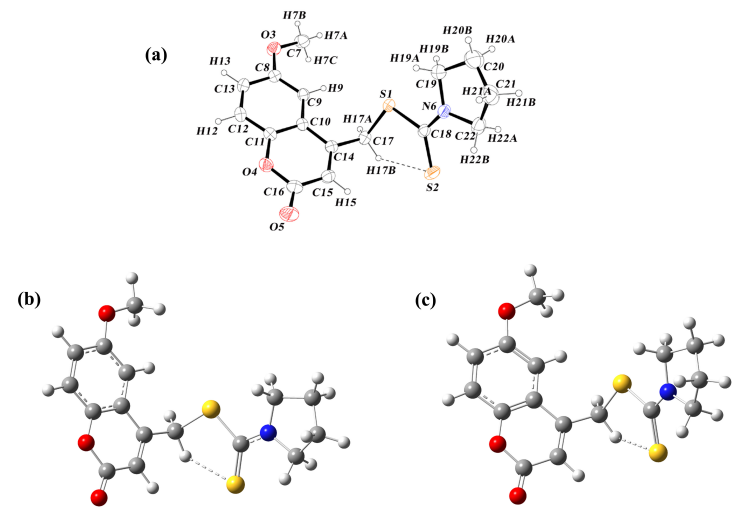

Fig. 1. (a) The experimental geometric structure of the title compound [18], (b) DFT optimized structure of the title compound, (c) HF optimized structure of the title compound.

It is well known that DFT-optimized bond lengths are usually longer and more accurate than HF due to the inclusion of electron correlation [27]. On the other hand, according to calculated results, the HF method correlates better for the bond distance compared with the DFT/B3LYP method (Table 1). The maximum difference of bond lengths between the experimental and the predicted values has been found at $\mathrm{C} 20-\mathrm{C} 21$ bond with the difference being $0.061 \AA$ for B3LYP method, and with a value $0.053 \AA$ for HF method. The root mean square error (RMSE) is obtained as $0.018 \AA$ for HF and $0.021 \AA$ for B3LYP, indicating that the bond lengths predicted by the HF method show a good correlation with the experimental values. For bond angles, the opposite trend was observed. As can be seen from Table 1, both the biggest difference and the RMSE for the bond angles calculated by the B3LYP method are smaller than those predicted by HF. A global comparing of the structures obtained by the theoretical calculations has been done by superimposing the molecular skeleton with that obtained from X-ray diffraction [28], giving a RMSE of $0.247 \AA$ for B3LYP and $0.324 \AA$ for HF method (Fig. 2). As a result, the B3LYP calculation well reproduces the the 3-D geometry of the title compound.
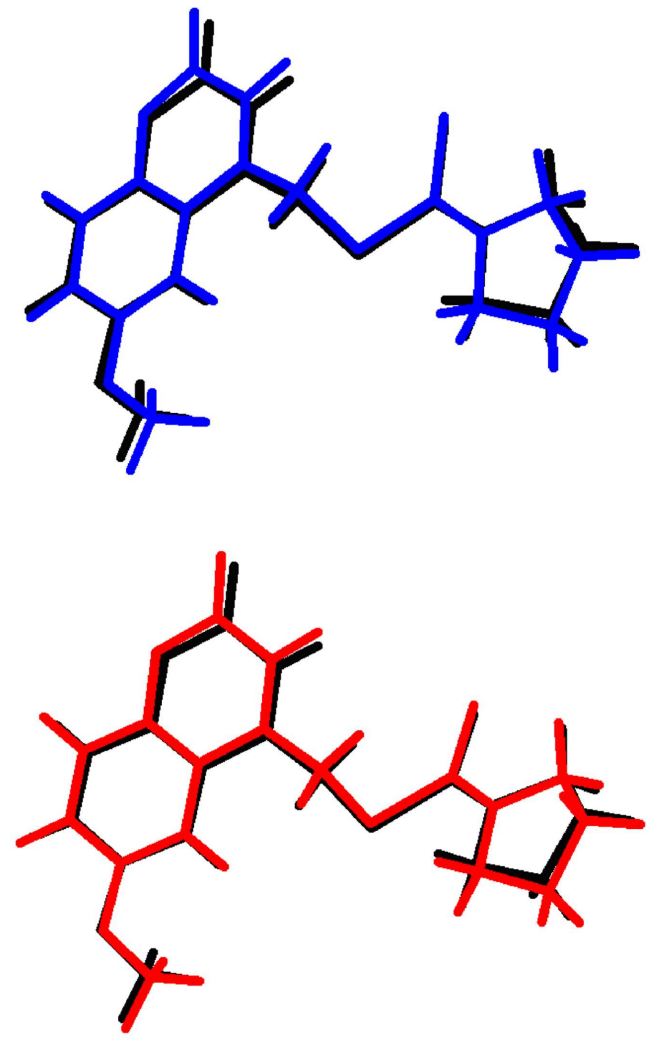

Fig. 2. Superimposition of the calculated HF (top) and DFT (bottom) and experimental structures of (6-Methoxy-2-oxo-2H-chromen-4-yl)methyl pyrrolidine-1-carbodithioate.

\subsection{Conformational analysis}

In order to define the preferential position of pyrrolidine and chrome rings, a preliminary search of low energy structures was performed using $\mathrm{B} 3 \mathrm{LYP} / 6-311++\mathrm{G}(\mathrm{d}, \mathrm{p})$ computations as a function of the selected degrees of torsional freedom T(S1-C18-N6-C19) and T(S1-C17-C14$\mathrm{C} 15)$. The respective values of the selected degrees of torsional freedom, T(S1-C18-N6-C19) and $\mathrm{T}(\mathrm{S} 1-\mathrm{C} 17-\mathrm{C} 14-\mathrm{C} 15)$, are $-0.81^{\circ}$ and $-99.34^{\circ}$ in X-ray structure [18], whereas the corresponding values in DFT optimized geometry are $-1.35^{\circ}$ and $-104.04^{\circ}$. Molecular energy profiles with respect to rotations about the selected torsion angles are presented in Fig. 3. 
Table 1. Selected molecular structure parameters.

\begin{tabular}{|c|c|c|c|}
\hline \multirow{2}{*}{ Parameters } & \multirow{2}{*}{ Experimental [18] } & \multicolumn{2}{|c|}{ Calculated $6-311++\mathrm{G}(\mathrm{d}, \mathrm{p})$} \\
\hline & & B3LYP & $\mathrm{HF}$ \\
\hline \multicolumn{4}{|l|}{ Bond lengths $[\AA]$} \\
\hline S1-C18 & $1.787(2)$ & 1.815 & 1.785 \\
\hline $\mathrm{S} 1-\mathrm{C} 17$ & $1.813(2)$ & 1.839 & 1.823 \\
\hline S2-C18 & $1.666(2)$ & 1.669 & 1.669 \\
\hline $\mathrm{O} 3-\mathrm{C} 8$ & $1.358(3)$ & 1.364 & 1.347 \\
\hline $\mathrm{O} 3-\mathrm{C} 7$ & $1.403(3)$ & 1.421 & 1.398 \\
\hline $\mathrm{O} 4-\mathrm{C} 16$ & $1.364(3)$ & 1.390 & 1.344 \\
\hline $\mathrm{O} 4-\mathrm{C} 11$ & $1.375(3)$ & 1.365 & 1.353 \\
\hline O5-C16 & $1.199(3)$ & 1.204 & 1.180 \\
\hline N6-C18 & $1.313(3)$ & 1.341 & 1.320 \\
\hline N6-C19 & $1.465(3)$ & 1.479 & 1.472 \\
\hline N6-C22 & $1.480(3)$ & 1.478 & 1.472 \\
\hline $\mathrm{C} 8-\mathrm{C} 9$ & $1.386(3)$ & 1.388 & 1.374 \\
\hline C8-C13 & $1.391(3)$ & 1.406 & 1.399 \\
\hline C9-C10 & $1.395(3)$ & 1.411 & 1.405 \\
\hline $\mathrm{C} 10-\mathrm{C} 11$ & $1.395(3)$ & 1.400 & 1.377 \\
\hline $\mathrm{C} 10-\mathrm{C} 14$ & $1.445(3)$ & 1.411 & 1.405 \\
\hline $\mathrm{C} 11-\mathrm{C} 12$ & $1.385(3)$ & 1.396 & 1.390 \\
\hline $\mathrm{C} 12-\mathrm{C} 13$ & $1.361(3)$ & 1.380 & 1.369 \\
\hline $\mathrm{C} 14-\mathrm{C} 15$ & $1.341(3)$ & 1.355 & 1.332 \\
\hline $\mathrm{C} 14-\mathrm{C} 17$ & $1.502(3)$ & 1.504 & 1.507 \\
\hline $\mathrm{C} 15-\mathrm{C} 16$ & $1.446(4)$ & 1.455 & 1.466 \\
\hline C19-C20 & $1.507(4)$ & 1.532 & 1.526 \\
\hline C20-C21 & $1.474(5)$ & 1.535 & 1.527 \\
\hline $\mathrm{C} 21-\mathrm{C} 22$ & $1.505(5)$ & 1.531 & 1.525 \\
\hline Max. difference ${ }^{\mathrm{a}}$ & & 0.061 & 0.053 \\
\hline RMSE & & 0.021 & 0.018 \\
\hline \multicolumn{4}{|l|}{ Bond angles $\left[{ }^{\circ}\right]$} \\
\hline $\mathrm{C} 18-\mathrm{S} 1-\mathrm{C} 17$ & $102.70(11)$ & 103.03 & 105.31 \\
\hline $\mathrm{C} 8-\mathrm{O} 3-\mathrm{C} 7$ & $118.4(2)$ & 118.57 & 119.95 \\
\hline C16-O4-C11 & $121.98(18)$ & 122.35 & 123.06 \\
\hline C18-N6-C19 & $126.0(2)$ & 126.05 & 126.07 \\
\hline C18-N6-C22 & $123.3(2)$ & 122.29 & 122.30 \\
\hline C19-N6-C22 & $110.6(2)$ & 111.64 & 111.61 \\
\hline $\mathrm{O} 3-\mathrm{C} 8-\mathrm{C} 9$ & $124.1(2)$ & 124.75 & 124.86 \\
\hline $\mathrm{O} 3-\mathrm{C} 8-\mathrm{C} 13$ & $115.9(2)$ & 115.39 & 115.54 \\
\hline C9-C8-C13 & $119.9(2)$ & 119.85 & 119.59 \\
\hline C8-C9-C10 & $120.1(2)$ & 120.49 & 120.54 \\
\hline
\end{tabular}


Table 1. (Continuation) Selected molecular structure parameters.

\begin{tabular}{|c|c|c|c|}
\hline \multirow{2}{*}{ Parameters } & \multirow{2}{*}{ Experimental [18] } & \multicolumn{2}{|c|}{ Calculated $6-311++\mathrm{G}(\mathrm{d}, \mathrm{p})$} \\
\hline & & B3LYP & $\mathrm{HF}$ \\
\hline C11-C10-C9 & $118.4(2)$ & 118.48 & 118.70 \\
\hline $\mathrm{C} 11-\mathrm{C} 10-\mathrm{C} 14$ & $117.6(2)$ & 117.46 & 117.19 \\
\hline C9-C10-C14 & $123.99(19)$ & 124.04 & 124.09 \\
\hline $\mathrm{O} 4-\mathrm{C} 11-\mathrm{C} 12$ & $116.88(19)$ & 116.76 & 116.65 \\
\hline $\mathrm{O} 4-\mathrm{C} 11-\mathrm{C} 10$ & $121.7(2)$ & 122.19 & 122.29 \\
\hline $\mathrm{C} 12-\mathrm{C} 11-\mathrm{C} 10$ & $121.4(2)$ & 121.03 & 121.04 \\
\hline $\mathrm{C} 13-\mathrm{C} 12-\mathrm{C} 11$ & $119.3(2)$ & 119.76 & 119.71 \\
\hline $\mathrm{C} 12-\mathrm{C} 13-\mathrm{C} 8$ & $120.9(2)$ & 120.35 & 120.38 \\
\hline C15-C14-C10 & $119.0(2)$ & 119.10 & 118.80 \\
\hline $\mathrm{C} 15-\mathrm{C} 14-\mathrm{C} 17$ & $121.1(2)$ & 119.94 & 120.25 \\
\hline $\mathrm{C} 10-\mathrm{C} 14-\mathrm{C} 17$ & $119.93(19)$ & 120.94 & 120.92 \\
\hline $\mathrm{C} 14-\mathrm{C} 15-\mathrm{C} 16$ & $123.0(2)$ & 122.99 & 122.28 \\
\hline $\mathrm{O} 5-\mathrm{C} 16-\mathrm{O} 4$ & $116.9(2)$ & 117.99 & 119.15 \\
\hline O5-C16-C15 & $126.6(3)$ & 126.11 & 124.49 \\
\hline $\mathrm{O} 4-\mathrm{C} 16-\mathrm{C} 15$ & $116.5(2)$ & 115.88 & 116.35 \\
\hline $\mathrm{C} 14-\mathrm{C} 17-\mathrm{S} 1$ & $110.94(16)$ & 112.80 & 113.25 \\
\hline N6-C18-S2 & $124.10(18)$ & 123.67 & 123.54 \\
\hline N6-C18-S1 & $111.67(17)$ & 111.57 & 112.58 \\
\hline S2-C18-S1 & $124.21(15)$ & 124.75 & 123.86 \\
\hline N6-C19-C20 & $104.6(2)$ & 103.67 & 103.58 \\
\hline $\mathrm{C} 21-\mathrm{C} 20-\mathrm{C} 19$ & $105.7(3)$ & 103.34 & 103.21 \\
\hline $\mathrm{C} 20-\mathrm{C} 21-\mathrm{C} 22$ & $105.6(3)$ & 103.57 & 103.41 \\
\hline N6-C22-C21 & $103.7(2)$ & 103.75 & 103.61 \\
\hline Max. Difference $^{\mathrm{a}}$ & & 2.36 & 2.61 \\
\hline RMSE & & 0.831 & 1.168 \\
\hline \multicolumn{4}{|l|}{ Torsion angles $\left[{ }^{\circ}\right]$} \\
\hline C22-N6-C18-S1 & 178.00 & 178.48 & 178.56 \\
\hline N6-C18-S1-C17 & -170.98 & -176.56 & -174.45 \\
\hline C18-S1-C17-C14 & 103.72 & 105.99 & 98.78 \\
\hline S1-C17-C14-C15 & -99.35 & -104.04 & -107.40 \\
\hline
\end{tabular}

${ }^{a}$ Maximum differences between the bond lengths and angles computed using theoretical methods and those obtained from X-ray diffraction

As can be seen from the Fig. 3, the low energy domains for T(S1-C18-N6-C19) are located at $0^{\circ}$ and $180^{\circ}$, while they are located at $-100^{\circ}$ and $120^{\circ}$ for $\mathrm{T}(\mathrm{S} 1-\mathrm{C} 17-\mathrm{C} 14-\mathrm{C} 15)$. Energy difference between the most favorable and unfavorable conformers, which arises from rotational potential barrier calculated with respect to the two selected torsion angles, is 0.036 Hartree for $\mathrm{T}(\mathrm{S} 1-\mathrm{C} 18-\mathrm{N} 6-$ C19) and 0.14 Hartree for T(S1-C17-C14-C15), when both selected degrees of torsional freedom are considered. It must be remarked that the selected torsion angles in the crystal structure of the title compound are close to the value in the global energy minimum. 

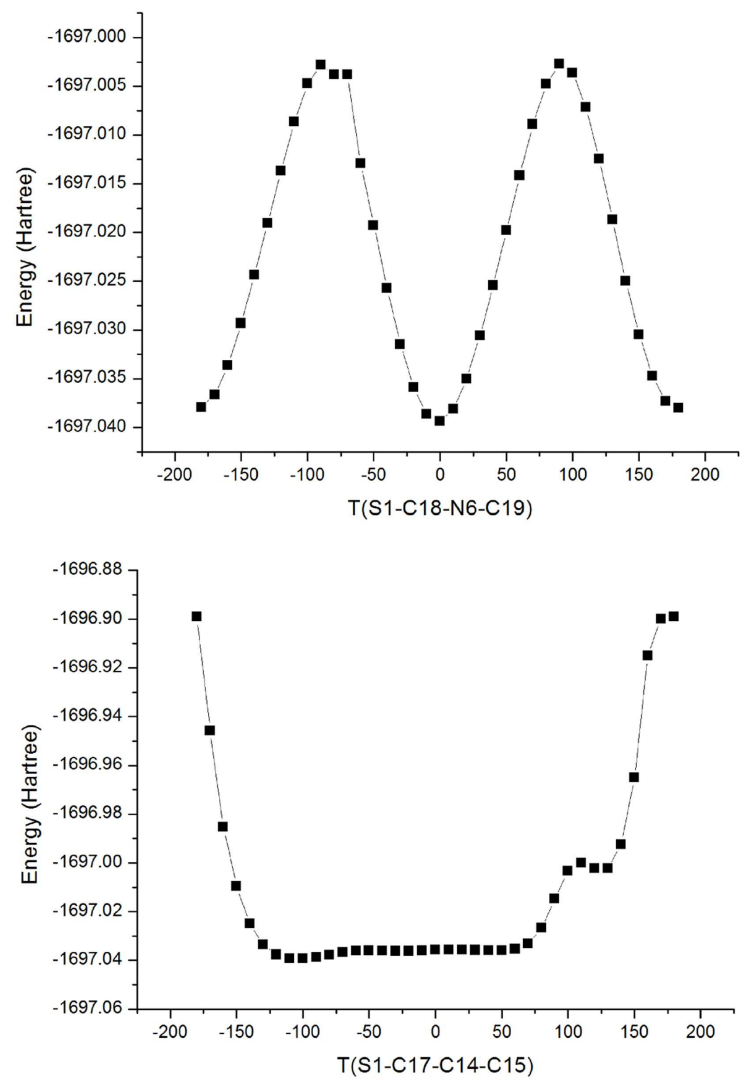

Fig. 3. Potential energy profile using the DFT/B3LYP method for the internal rotation around the $\mathrm{C} 18$ N6 and C17-C14 bonds.

\subsection{Vibrational analysis}

In this study, harmonic vibrational frequencies were calculated using the DFT/B3LYP and HF methods with the $6-311++\mathrm{G}(\mathrm{d}, \mathrm{p})$ basis set. Using the Gauss-View molecular visualisation program, the vibrational band assignments were made. In order to facilitate assignment of the observed peaks, the vibrational frequencies have been analyzed and the calculation for the title compound have been compared with the experimental results. The vibrational frequencies in the region $4000 \mathrm{~cm}^{-1}$ to $600 \mathrm{~cm}^{-1}$ are given in Table 2. The IR spectra contain some characteristic bands of the stretching vibrations of the $\mathrm{C}-\mathrm{H}, \mathrm{C}-\mathrm{H}_{2}, \mathrm{C}-\mathrm{H}_{3}, \mathrm{C}=\mathrm{O}, \mathrm{C}-\mathrm{O}, \mathrm{C}-\mathrm{N}, \mathrm{C}=\mathrm{S}$ and $\mathrm{C}-\mathrm{S}$ groups.

\subsubsection{C-H vibrations}

$\mathrm{C}-\mathrm{H}$ is known as characteristic vibrational frequency. In the literature, the in-plane and out-of-plane bending vibrational frequencies are obtained within their characteristic region. The aromatic compounds commonly exhibit $\mathrm{C}-\mathrm{H}$ stretching vibrations in the region of $3150 \mathrm{~cm}^{-1}$ to $2900 \mathrm{~cm}^{-1}[29,30]$ which is the characteristic region for the ready identification of $\mathrm{C}-\mathrm{H}$ stretching vibrations in plane. In this region the bands are not appreciably affected by the nature of the substituents. In our present work, $\mathrm{C}-\mathrm{H}$ aromatic stretching are of medium intensity and in the expected region, lie within the range of $3089 \mathrm{~cm}^{-1}$ to $3078 \mathrm{~cm}^{-1}$ by B3LYP and $3019 \mathrm{~cm}^{-1}$ to $2998 \mathrm{~cm}^{-1}$ by HF. Also C-H in-plane and outof-plane bending vibrations were observed in the range of $1300 \mathrm{~cm}^{-1}$ to $1000 \mathrm{~cm}^{-1}$ and $900 \mathrm{~cm}^{-1}$ to $675 \mathrm{~cm}^{-1}$ [31], respectively. In the title compound, $\mathrm{C}-\mathrm{H}$ aromatic rocking bands have been found at $1348 \mathrm{~cm}^{-1}, 1184 \mathrm{~cm}^{-1}$ and $1092 \mathrm{~cm}^{-1}$ by B3LYP and at $1344 \mathrm{~cm}^{-1}, 1205 \mathrm{~cm}^{-1}$ and $1076 \mathrm{~cm}^{-1}$ by $\mathrm{HF}$ method. Besides, $\mathrm{C}-\mathrm{H}$ aromatic wagging bands are only out-of-plane bending vibrations which is observed at $871 \mathrm{~cm}^{-1}, 816 \mathrm{~cm}^{-1}$ and $728 \mathrm{~cm}^{-1}$ by B3LYP and $887 \mathrm{~cm}^{-1}, 832 \mathrm{~cm}^{-1}$ and $731 \mathrm{~cm}^{-1}$ by HF. Rahman et al. [32] has found the wagging type vibrations of the $\mathrm{C}-\mathrm{H}$ bonds at $820 \mathrm{~cm}^{-1}$ and $794 \mathrm{~cm}^{-1}$ theoretically, which correlates nicely with an experimental peak at $800 \mathrm{~cm}^{-1}$.

\subsubsection{Methyl group vibrations}

The title molecule possesses one $\mathrm{C}-\mathrm{H}_{3}$ group. The $\mathrm{C}-\mathrm{H}$ methyl group stretching vibrations are highly localized and generally observed in the range of $3000 \mathrm{~cm}^{-1}$ to $2900 \mathrm{~cm}^{-1}[31,33]$. In 7-Methoxy-4-methylcoumarin, the bands observed at $3001 \mathrm{~cm}^{-1}, 2964 \mathrm{~cm}^{-1}, 2951 \mathrm{~cm}^{-1}$ in FT-IR spectrum and the bands observed at $3000 \mathrm{~cm}^{-1}$ and $2951 \mathrm{~cm}^{-1}$ in Raman spectrum were assigned to $\mathrm{CH}_{3}$ asymmetric stretching vibrations [34]. The $\mathrm{CH}_{3}$ symmetric stretching vibrations were observed at $2902 \mathrm{~cm}^{-1}$ and $2855 \mathrm{~cm}^{-1}$ in the FT-IR spectrum [34]. In this study, the peaks calculated at $3011 \mathrm{~cm}^{-1}$ and $2938 \mathrm{~cm}^{-1}$ for B3LYP and $2924 \mathrm{~cm}^{-1}$ and $2866 \mathrm{~cm}^{-1}$ for $\mathrm{HF}$ are assigned to asymmetric stretching of the methyl group. 
The symmetric one is calculated at $2883 \mathrm{~cm}^{-1}$ and $2813 \mathrm{~cm}^{-1}$ for B3LYP and HF levels, respectively. $\mathrm{CH}_{3}$ scissoring vibration is also identified at $1460 \mathrm{~cm}^{-1}$ for B3LYP, while wagging vibrations are identified at $1444 \mathrm{~cm}^{-1}, 1184 \mathrm{~cm}^{-1}$, $1158 \mathrm{~cm}^{-1}$ and $1120 \mathrm{~cm}^{-1}$ and $1450 \mathrm{~cm}^{-1}$, $1205 \mathrm{~cm}^{-1}, 1181 \mathrm{~cm}^{-1}$ and $1045 \mathrm{~cm}^{-1}$ for B3LYP and HF, respectivly. The calculated wavenumbers of $\mathrm{CH}_{3}$ group vibrations show the good correlation with the data presented in the literature [35-37].

\subsubsection{Methylene vibrations}

The asymmetric $\mathrm{CH}_{2}$ stretching vibrations are generally observed above $3000 \mathrm{~cm}^{-1}$, while the symmetric stretch appears between $3000 \mathrm{~cm}^{-1}$ and $2900 \mathrm{~cm}^{-1}$ [38]. The $\mathrm{CH}_{2}$ asymmetric stretching vibration was calculated at $2985 \mathrm{~cm}^{-1}$ for B3LYP and at $2889 \mathrm{~cm}^{-1}$ for $\mathrm{HF}$, while the symmetric stretching vibrations were predicted at $2926 \mathrm{~cm}^{-1}$ and $2924 \mathrm{~cm}^{-1}$ for B3LYP and at $2887 \mathrm{~cm}^{-1}$ and $2883 \mathrm{~cm}^{-1}$ for HF. Similar vibrational modes were also observed for free pyrrolidine [39] or cyclopentene [40] and other pyrrolidine derivatives [41]. The $\mathrm{CH}_{2}$ two wagging and two twisting out-of-plane deformation vibrations were calculated at $1319 \mathrm{~cm}^{-1}$ and $1184 \mathrm{~cm}^{-1}$ for B3LYP and at $1335 \mathrm{~cm}^{-1}$ and $1205 \mathrm{~cm}^{-1}$ for $\mathrm{HF}$ and at $1158 \mathrm{~cm}^{-1}$ and $1128 \mathrm{~cm}^{-1}$ for B3LYP and at $1181 \mathrm{~cm}^{-1}$ for $\mathrm{HF}$, respectively. The band at $910 \mathrm{~cm}^{-1}$ was assigned to $\mathrm{CH}_{2}$ rocking in-plane deformation vibration [42]. In the present work, the same vibrations were calculated at $900 \mathrm{~cm}^{-1}$ by B3LYP and at $935 \mathrm{~cm}^{-1}$ by HF.

\subsection{4. $\mathrm{C}=\mathrm{O}$ and $\mathrm{C}-\mathrm{O}$ vibrations}

Coumarin derivative compounds have two characteristic absorption bands arising from $\mathrm{C}=\mathrm{O}$ and $\mathrm{C}-\mathrm{O}$ stretching vibrations. The $\mathrm{C}=\mathrm{O}$ stretching frequency appears strongly in the IR spectrum in the range of $1600 \mathrm{~cm}^{-1}$ to $1850 \mathrm{~cm}^{-1}$ because of the large change in dipole moment. The carbonyl group vibrations give rise to characteristic bands in vibration spectra and the characteristic frequency used to study a wide range of compounds. The intensity of these bands can increase owing to conjugation or formation of hydrogen bonds [43]. Moghaddam et al. [44] assigned $\mathrm{C}=\mathrm{O}$ stretching absorption in the region of $1744 \mathrm{~cm}^{-1}$ to $1717 \mathrm{~cm}^{-1}$ for 3-benzyl-2Hpyrano3,2-chromene-2,5(6H)-dione. In 4-hydroxy1-thiocoumarin, the $\mathrm{C}=\mathrm{O}$ stretching was found to be present at $1701 \mathrm{~cm}^{-1}$ [43]. In the present study, chromene $(\mathrm{C}=\mathrm{O})$ bond stretching vibration was observed at $1708 \mathrm{~cm}^{-1}$ experimentally [18], while it has been calculated at $1722 \mathrm{~cm}^{-1}$ for B3LYP and at $1767 \mathrm{~cm}^{-1}$ for HF. The experimental $\mathrm{C}-\mathrm{O}$ stretching bands were observed at $1036 \mathrm{~cm}^{-1}$ and $1279 \mathrm{~cm}^{-1}$, and were calculated at $900 \mathrm{~cm}^{-1}$ to $1214 \mathrm{~cm}^{-1}$ for B3LYP and at $935 \mathrm{~cm}^{-1}$ to $1233 \mathrm{~cm}^{-1}$ for HF. These values are in good agreement with the similar compounds $[45,46]$.

\subsection{5. $\quad \mathrm{C}-\mathrm{N}$ vibrations}

The calculation of $\mathrm{C}-\mathrm{N}$ stretching frequency is a rather hard job since there are problems in identifying these frequencies from other vibrations [47]. Silverstein et al. [31] identified the C-N stretching absorption in the region of $1382 \mathrm{~cm}^{-1}$ to $1266 \mathrm{~cm}^{-1}$ for aromatic amines. Tecklenburg et al. [48] located the $\mathrm{C}-\mathrm{N}$ symmetric stretch in the region of $1120 \mathrm{~cm}^{-1}$ to $1150 \mathrm{~cm}^{-1}$. The $\mathrm{C}-\mathrm{N}$ stretchings were also found to be present at $1248 \mathrm{~cm}^{-1}$ and $1199 \mathrm{~cm}^{-1}$ by Pajazk et al. [49]. In this study, the $\mathrm{C}-\mathrm{N}$ stretching vibrations were calculated at $1389 \mathrm{~cm}^{-1}, 1128 \mathrm{~cm}^{-1}$ and $835 \mathrm{~cm}^{-1}$ by B3LYP and at $1389 \mathrm{~cm}^{-1}, 1181 \mathrm{~cm}^{-1}$ and $843 \mathrm{~cm}^{-1}$ by HF.

\subsubsection{C-C vibrations}

The aromatic stretching vibrations are very prominent, as they involve double $\mathrm{C}=\mathrm{C}$ bond in conjugation with the ring. The ring $\mathrm{C}=\mathrm{C}$ and $\mathrm{C}-\mathrm{C}$ stretching vibrations are expected within the region of $1620 \mathrm{~cm}^{-1}$ to $1390 \mathrm{~cm}^{-1}$ [50]. The $\mathrm{C}=\mathrm{C}$ stretching vibrations of the title compound with very strong intensity are predicted at $1594 \mathrm{~cm}^{-1}$, $1581 \mathrm{~cm}^{-1}, 1536 \mathrm{~cm}^{-1}$ and $1460 \mathrm{~cm}^{-1}$ for B3LYP level and at $1604 \mathrm{~cm}^{-1}, 1566 \mathrm{~cm}^{-1}$ and $1475 \mathrm{~cm}^{-1}$ for $\mathrm{HF}$ level. These olefinic $\mathrm{C}=\mathrm{C}$ stretching vibrations are also in good agreement with the experimental (at $1590 \mathrm{~cm}^{-1}, 1558 \mathrm{~cm}^{-1}, 1544 \mathrm{~cm}^{-1}$ and $\left.1482 \mathrm{~cm}^{-1}\right)$ and theoretical $\left(1588 \mathrm{~cm}^{-1}\right.$, $1583 \mathrm{~cm}^{-1}, 1541 \mathrm{~cm}^{-1}$ and $\left.1508 \mathrm{~cm}^{-1}\right)$ values [51]. The stretching vibrational bands for 
$\mathrm{C}-\mathrm{C}$ bond were calculated at $1348 \mathrm{~cm}^{-1}$ and $1319 \mathrm{~cm}^{-1}$ for B3LYP and at $1344 \mathrm{~cm}^{-1}$ and $1335 \mathrm{~cm}^{-1}$ for HF.

\subsection{7. $\mathrm{C}=\mathrm{S}$ and $\mathrm{C}-\mathrm{S}$ vibrations}

According to Silverstein et al. [52], the spectra of the compounds in which $\mathrm{C}=\mathrm{S}$ group is attached to an $\mathrm{N}$ atom show absorption bands in the broad region of $1563 \mathrm{~cm}^{-1}$ to $700 \mathrm{~cm}^{-1}$. In nitrogen containing thiocarbonyl compounds, the assignment of the $\mathrm{C}=\mathrm{S}$ stretching frequency has been controversial [53-55]. Mani et al. [56] have reported an absorption band in phenylisothiocynate near $988 \mathrm{~cm}^{-1}$. The absorption bands in the region of $1180 \mathrm{~cm}^{-1}$ to $1150 \mathrm{~cm}^{-1}$ have been assigned to the $\mathrm{C}=\mathrm{S}$ stretching vibrations in thiohydroxamic acids [57]. In this study, the $\mathrm{C}=\mathrm{S}$ stretching vibration, calculated at $974 \mathrm{~cm}^{-1}$ for B3LYP and at $972 \mathrm{~cm}^{-1}$ for HF. The C-S group is less polar than carbonyl links and has a considerably weaker band. In consequence, the bond is not intense, and it falls at lower frequencies [58]. Tanak et al. [59] assigned this mode at $680 \mathrm{~cm}^{-1}$ and $497 \mathrm{~cm}^{-1}$ in FT-IR spectrum. The $\mathrm{C}-\mathrm{S}$ stretching mode was observed at $672 \mathrm{~cm}^{-1}$ for trifluoperazine [60]. In our title molecule the $\mathrm{C}-\mathrm{S}$ stretching is observed at $660 \mathrm{~cm}^{-1}$ in FT-IR spectrum [18]. This band is found to be $666 \mathrm{~cm}^{-1}$ and $801 \mathrm{~cm}^{-1}$ for HF, and $674 \mathrm{~cm}^{-1}$ and $792 \mathrm{~cm}^{-1}$ for B3LYP.

\subsection{Proton and carbon-13 NMR chemical shift analyses}

GIAO ${ }^{1} \mathrm{H}$ and ${ }^{13} \mathrm{C}$ chemical shift values were calculated using B3LYP and HF methods with the $6-311++\mathrm{G}(\mathrm{d}, \mathrm{p})$ basis set in gas phase and the calculated results are given in Table 3 . To investigate the solvent effect on the chemical shift values of the compound, based on B3LYP and HF method and IEF-PCM model, two solvents ( $\varepsilon=46.7$, DMSO; $\varepsilon=24.55$, ethanol) were selected and the calculated values were also listed in Table 3. Relative chemical shifts were estimated by using the TMS shielding calculated in advance at the same theoretical level as the reference. Calculated ${ }^{1} \mathrm{H}$ isotropic chemical shielding for TMS at the HF(gas), B3LYP(gas), HF(ethanol), B3LYP(ethanol), HF(DMSO) and B3LYP(DMSO) are 32.44 ppm, 31.97 ppm, 32.43 ppm, 31.96 ppm, $32.43 \mathrm{ppm}$ and $31.96 \mathrm{ppm}$, respectively. Also, calculated ${ }^{13} \mathrm{C}$ isotropic chemical shielding for TMS at the HF (gas), B3LYP (gas), HF (ethanol), B3LYP (ethanol), HF (DMSO) and B3LYP (DMSO) are $196.11 \mathrm{ppm}, 184.06 \mathrm{ppm}, 196.58 \mathrm{ppm}$, $184.54 \mathrm{ppm}, 196.59 \mathrm{ppm}$ and $184.66 \mathrm{ppm}$, respectively.

We have calculated ${ }^{1} \mathrm{H}$ chemical shift values (with respect to TMS) of $1.89 \mathrm{ppm}$ to $7.37 \mathrm{ppm}$ at the B3LYP (gas) and $1.73 \mathrm{ppm}$ to $7.81 \mathrm{ppm}$ at HF (gas) level. Besides, they were calculated to be $2.00 \mathrm{ppm}$ to $7.48 \mathrm{ppm}$ at the B3LYP (ethanol), $1.71 \mathrm{ppm}$ to $7.80 \mathrm{ppm}$ at the HF (ethanol), $2.00 \mathrm{ppm}$ to $7.49 \mathrm{ppm}$ at the B3LYP (DMSO) and $1.71 \mathrm{ppm}$ to $7.80 \mathrm{ppm}$ at the HF (DMSO). In (S)-2Oxopyrrolidin-1-yl Butanamide [61], $\mathrm{CH}_{2}$ protons of the pyrrolidine ring are observed in the region of $2.47 \mathrm{ppm}$ to $4.50 \mathrm{ppm}$. In our study, $\mathrm{CH}_{2}$ protons of the pyrrolidine ring are found in the region of $1.89 \mathrm{ppm}$ to $4.30 \mathrm{ppm}$ at all the B3LYP levels and $1.73 \mathrm{ppm}$ to $3.88 \mathrm{ppm}$ at all the HF levels. In the 3-(1-((methoxycarbonyl)oxy)imino)ethyl)$2 \mathrm{H}$-chromen-2-one, the chemical schift values of chromene ring protons were observed at $7.28 \mathrm{ppm}$ to $8.08 \mathrm{ppm}$ experimentally, and at $7.05 \mathrm{ppm}$ to $7.91 \mathrm{ppm}$ for the $\mathrm{HF} / 6-311++\mathrm{G}(\mathrm{d}, \mathrm{p})$ level and $7.26 \mathrm{ppm}$ to $8.41 \mathrm{ppm}$ for the B3LYP/6$311++\mathrm{G}(\mathrm{d}, \mathrm{p})$ level [62]. In the present work, the chromene ring protons have been calculated at $6.80 \mathrm{ppm}$ to $7.87 \mathrm{ppm}$ for B3LYP and at $6.73 \mathrm{ppm}$ to $7.81 \mathrm{ppm}$ for HF levels in gas and solution phase.

The ${ }^{13} \mathrm{C}$ NMR chemical shift values (with respect to TMS) have been calculated to be $28.69 \mathrm{ppm}$ to $205.44 \mathrm{ppm}$ for B3LYP (gas), $24.57 \mathrm{ppm}$ to $226.88 \mathrm{ppm}$ for HF (gas), $29.23 \mathrm{ppm}$ to $206.75 \mathrm{ppm}$ for B3LYP (ethanol), $25.04 \mathrm{ppm}$ to $227.35 \mathrm{ppm}$ for HF (ethanol), $29.35 \mathrm{ppm}$ to $206.97 \mathrm{ppm}$ for B3LYP (DMSO) and $25.05 \mathrm{ppm}$ to $227.36 \mathrm{ppm}$ for HF (DMSO). The chromene ring carbons give peaks at $100 \mathrm{ppm}$ to $200 \mathrm{ppm}$ for all methods. These peaks have been observed at $113 \mathrm{ppm}$ to $177 \mathrm{ppm}$ in 7-Acetoxy-4(bromomethyl)coumarin [63]. As seen from Table $3,{ }^{1} \mathrm{H}$ and ${ }^{13} \mathrm{C}$ NMR spectra were a little affected by the change in polarity of the solvent. 
Table 2. Comparison of the experimental and calculated vibrational frequencies $\left[\mathrm{cm}^{-1}\right]$.

\begin{tabular}{|c|c|c|c|}
\hline \multirow{2}{*}{ Assignments $^{\mathrm{a}}$} & \multirow{2}{*}{ Experimental [18] } & \multicolumn{2}{|c|}{ Scaled frequencies with $6-311++\mathrm{G}(\mathrm{d}, \mathrm{p})$} \\
\hline & & B3LYP & $\mathrm{HF}$ \\
\hline$v(\mathrm{C}-\mathrm{H})$ ring & - & 3089 & 3019 \\
\hline$v(\mathrm{C}-\mathrm{H})$ ring & - & 3083 & 3015 \\
\hline$v(\mathrm{C}-\mathrm{H})$ ring & - & 3078 & 2998 \\
\hline$v\left(\mathrm{C}-\mathrm{H}_{3}\right)$ as & - & 3011 & 2924 \\
\hline$v\left(\mathrm{C}-\mathrm{H}_{2}\right)$ as & - & 2985 & 2889 \\
\hline$v\left(\mathrm{C}-\mathrm{H}_{2}\right) \mathrm{s}$ & - & 2926 & 2887 \\
\hline$v\left(\mathrm{C}-\mathrm{H}_{3}\right)$ as & - & 2938 & 2866 \\
\hline$v\left(\mathrm{C}-\mathrm{H}_{2}\right) \mathrm{s}$ & - & 2924 & 2883 \\
\hline$v\left(\mathrm{C}-\mathrm{H}_{3}\right) \mathrm{s}$ & - & 2883 & 2813 \\
\hline$v(\mathrm{C}=\mathrm{O})$ & 1708 & 1722 & 1767 \\
\hline$v(\mathrm{C}=\mathrm{C})$ & - & 1594 & 1604 \\
\hline$v(\mathrm{C}=\mathrm{C})$ ring & - & 1581 & 1566 \\
\hline$v(\mathrm{C}=\mathrm{C})$ ring & - & 1536 & 1475 \\
\hline$v(\mathrm{C}=\mathrm{C})+\alpha\left(\mathrm{C}-\mathrm{H}_{3}\right)$ & - & 1460 & - \\
\hline$\omega\left(\mathrm{C}-\mathrm{H}_{3}\right)$ & - & 1444 & 1450 \\
\hline$v(\mathrm{C}-\mathrm{N})$ & - & 1389 & 1389 \\
\hline$v(\mathrm{C}-\mathrm{C})+\gamma(\mathrm{C}-\mathrm{H})$ ring & - & 1348 & 1344 \\
\hline$v(\mathrm{C}-\mathrm{C})+\omega\left(\mathrm{C}-\mathrm{H}_{2}\right)$ & - & 1319 & 1335 \\
\hline$\gamma(\mathrm{C}-\mathrm{H})$ ring & - & 1246 & 1251 \\
\hline$v(\mathrm{C}-\mathrm{O})$ ring $+v(\mathrm{C}-\mathrm{O})$ methoxy & 1279 & 1214 & 1233 \\
\hline$\gamma(\mathrm{C}-\mathrm{H})$ ring $+\omega\left(\mathrm{C}-\mathrm{H}_{2}\right)+\omega\left(\mathrm{C}-\mathrm{H}_{3}\right)$ & - & 1184 & 1205 \\
\hline$\delta\left(\mathrm{C}-\mathrm{H}_{2}\right)+\omega\left(\mathrm{C}-\mathrm{H}_{3}\right)$ & - & 1158 & 1181 \\
\hline$v(\mathrm{C}-\mathrm{N})+\delta\left(\mathrm{C}-\mathrm{H}_{2}\right)$ & - & 1128 & 1181 \\
\hline$\omega\left(\mathrm{C}-\mathrm{H}_{3}\right)$ & - & 1120 & 1045 \\
\hline$\gamma(\mathrm{C}-\mathrm{H})$ ring & - & 1109 & 1045 \\
\hline$\gamma(\mathrm{C}-\mathrm{H})$ ring $+\gamma(\mathrm{C}-\mathrm{O})$ ring & - & 1092 & 1076 \\
\hline$v(\mathrm{C}-\mathrm{O})$ methoxy & 1036 & 1024 & 1045 \\
\hline$v(\mathrm{C}=\mathrm{S})$ & - & 974 & 972 \\
\hline$v(\mathrm{C}-\mathrm{O})$ ring $+\gamma\left(\mathrm{C}-\mathrm{H}_{2}\right)$ & - & 900 & 935 \\
\hline$\omega(\mathrm{C}-\mathrm{H}) \operatorname{ring}$ & - & 871 & 887 \\
\hline$v(\mathrm{C}-\mathrm{N})$ & 842 & 835 & 843 \\
\hline$\omega(\mathrm{C}-\mathrm{H})$ ring & - & 816 & 832 \\
\hline$v(\mathrm{C}-\mathrm{S})+\beta\left(\mathrm{C}-\mathrm{H}_{2}\right)$ & - & 792 & 801 \\
\hline$\omega(\mathrm{C}-\mathrm{H})$ ring & - & 728 & 731 \\
\hline$v(\mathrm{C}-\mathrm{S})$ & 660 & 674 & 666 \\
\hline
\end{tabular}

a: $\gamma$ - stretching; $\delta$ - twisting; $\gamma$ - rocking; $\omega$, wagging; $\alpha$, scissoring; $\beta$, bending; s, symmetric; as asymmetric 
${ }^{1} \mathrm{H}$ and ${ }^{13} \mathrm{C}$ chemical shift results of the title compound in gas phase are generally closer to the solvent phase. The calculated ${ }^{1} \mathrm{H}$ and ${ }^{13} \mathrm{C}$ chemical shift values of the title compound are in a good agreement with those of related chromene and pyrrolidine derivatives $[64,65]$.

Table 3. Theoretical and experimental ${ }^{1} \mathrm{H}$ and ${ }^{13} \mathrm{C}$ isotropic chemical shifts (with respect to TMS values in $\mathrm{ppm}$ ) for the title compound.

\begin{tabular}{ccccccc}
\hline \multirow{2}{*}{ Atom } & \multicolumn{2}{c}{ Gas } & \multicolumn{2}{c}{ Ethanol } & \multicolumn{2}{c}{ DMSO } \\
\cline { 2 - 7 } & B3LYP & HF & B3LYP & HF & B3LYP & HF \\
\hline \hline H7A & 3.75 & 3.67 & 3.92 & 3.65 & 3.93 & 3.63 \\
H7B & 4.14 & 4.04 & 4.24 & 4.03 & 4.24 & 4.03 \\
H7C & 3.69 & 3.64 & 3.88 & 3.62 & 3.89 & 3.65 \\
H9 & 6.71 & 7.03 & 7.06 & 7.00 & 7.07 & 7.02 \\
H12 & 7.37 & 7.81 & 7.48 & 7.80 & 7.49 & 7.80 \\
H13 & 7.30 & 7.75 & 7.48 & 7.73 & 7.49 & 7.74 \\
H15 & 6.80 & 6.73 & 6.77 & 6.73 & 6.77 & 6.72 \\
H17A & 4.00 & 4.03 & 4.33 & 3.99 & 4.35 & 4.01 \\
H17B & 5.50 & 5.24 & 5.46 & 5.23 & 5.45 & 5.23 \\
H19A & 3.40 & 3.08 & 3.47 & 3.06 & 3.47 & 3.06 \\
H19B & 3.76 & 3.46 & 3.82 & 3.44 & 3.82 & 3.45 \\
H20A & 1.98 & 1.87 & 2.11 & 1.85 & 2.12 & 1.86 \\
H20B & 2.07 & 1.94 & 2.13 & 1.93 & 2.13 & 1.93 \\
H21A & 1.89 & 1.73 & 2.00 & 1.71 & 2.00 & 1.71 \\
H21B & 1.95 & 1.92 & 2.08 & 1.91 & 2.08 & 1.91 \\
H22A & 3.75 & 3.39 & 3.77 & 3.38 & 3.77 & 3.38 \\
H22B & 4.30 & 3.88 & 4.24 & 3.88 & 4.18 & 3.87 \\
C7 & 56.76 & 50.26 & 57.92 & 50.70 & 58.08 & 50.73 \\
C8 & 163.38 & 159.94 & 164.94 & 160.39 & 165.10 & 160.41 \\
C9 & 106.50 & 109.31 & 109.16 & 109.62 & 109.44 & 109.74 \\
C10 & 126.16 & 122.12 & 126.87 & 122.58 & 127.00 & 122.60 \\
C11 & 158.96 & 151.76 & 158.40 & 152.26 & 158.49 & 152.25 \\
C12 & 124.72 & 127.27 & 124.96 & 127.81 & 125.04 & 127.77 \\
C13 & 127.92 & 130.96 & 129.74 & 131.39 & 129.90 & 131.43 \\
C14 & 159.64 & 164.12 & 164.81 & 164.28 & 165.16 & 164.50 \\
C15 & 122.61 & 119.57 & 120.63 & 120.23 & 120.64 & 120.11 \\
C16 & 163.72 & 164.98 & 167.21 & 165.29 & 167.44 & 165.41 \\
C17 & 42.95 & 33.34 & 43.17 & 33.80 & 43.29 & 33.82 \\
C18 & 205.44 & 226.88 & 206.75 & 227.35 & 206.97 & 227.36 \\
C19 & 53.29 & 47.80 & 55.25 & 48.20 & 55.44 & 48.26 \\
C20 & 30.86 & 26.30 & 31.46 & 26.76 & 31.59 & 26.78 \\
C21 & 28.69 & 24.57 & 29.23 & 25.04 & 29.35 & 25.05 \\
C22 & 60.29 & 53.03 & 62.20 & 53.45 & 62.38 & 53.50 \\
\hline & & & & & &
\end{tabular}

\subsection{Natural bond orbital analysis}

NBO analysis provides an efficient method for studying intra and intermolecular hydrogen bonding and interaction among bonds, and provides a convenient basis for investigating charge transfer or conjugative interaction in molecular systems. The energy of hyperconjugative interactions or the stabilization energy gives the interaction between donor groups and acceptor ones [66, 67]. More intensive interactions between electron donors and electron acceptors depend on larger $\mathrm{E}^{(2)}$ value, i.e., the more donating tendency from electron donors to electron acceptors the greater the extent of conjugation of the whole system [68]. For each donor NBO (i) and acceptor NBO (j), the stabilization energy $E^{(2)}$ is estimated by the following equation $[69,70]$ :

$$
E^{(2)}=-q_{i} \frac{\left(F_{i j}\right)^{2}}{\varepsilon_{j}-\varepsilon_{i}}
$$

where $\mathrm{q}_{\mathrm{i}}$ is the donor orbital occupancy, $\varepsilon_{\mathrm{i}}, \varepsilon_{\mathrm{j}}$ are diagonal elements (orbital energies) and $\mathrm{F}_{\mathrm{ij}}$ is the off-diagonal NBO Fock matrix element. In order to investigate the intramolecular interaction, the stabilization energies of the title compound were performed using the second-order perturbation theory. The results of second-order perturbation theory analysis of the Fock Matrix at B3LYP/6$311++\mathrm{G}(\mathrm{d}, \mathrm{p})$ level of theory are collected in Table 4. For the table, the stabilization energies larger than $13 \mathrm{~kJ} / \mathrm{mol}$ have been chosen.

The NBO analysis has revealed that the intramolecular interactions which are formed by the orbital overlap between bonding $(\mathrm{C}-\mathrm{S}),(\mathrm{C}-\mathrm{O})$, $(\mathrm{C}-\mathrm{N}),(\mathrm{C}-\mathrm{C})$ and $(\mathrm{C}-\mathrm{H})$ anti-bonding orbital, result in intramolecular charge transfer causing stabilization of the compound. These interactions are observed as an increase in electron density (ED) in $(\mathrm{C}-\mathrm{S}),(\mathrm{C}-\mathrm{C})$ and $(\mathrm{C}-\mathrm{O})$ anti-bonding orbitals that weakens the respective bonds. The electron density of the five conjugated single bonds of pyrrolidine ring ( $\sim 1.98$ e) clearly demonstrates strong delocalization. Additionally, the ED of conjugated bond of $2 \mathrm{H}$-chromene ring $(\sim 1.91 \mathrm{e})$ clearly shows strong delocalization inside the compound [59]. 
In the studied compound, strong intramolecular hyperconjugative interactions of $\pi$-electrons with the greater energy contributions from C8-C9 $\rightarrow$ C10-C11 (73.94 kJ/mol), $\mathrm{C} 12-\mathrm{C} 13 \quad(69.93 \quad \mathrm{~kJ} / \mathrm{mol}) ; \quad \mathrm{C} 10-\mathrm{C} 11 \rightarrow$ C8-C9 (74.48 kJ/mol), C12-C13 (71.68 kJ/mol); $\mathrm{C} 14-\mathrm{C} 15 \quad(42.21 \quad \mathrm{~kJ} / \mathrm{mol}) ; \quad \mathrm{C} 12-\mathrm{C} 13 \rightarrow$ C8-C9 (80.67 kJ/mol), C10-C11 (75.53 kJ/mol); $\mathrm{C} 14-\mathrm{C} 15 \rightarrow$ O5-C16 (91.54 kJ/mol), C10-C11 $(43.76 \mathrm{~kJ} / \mathrm{mol})$ are observed for the chromene part of the compound. The hyperconjugative interactions of the $\sigma \rightarrow \sigma^{*}$ and $\sigma \rightarrow \pi^{*}$ transitions occur also from various bonds in the compound, such as the hyperconjugative interaction of the $\sigma(\mathrm{C} 22-\mathrm{H} 22 \mathrm{~B})$ distribute to $\sigma^{*}(\mathrm{C} 22-\mathrm{H} 22 \mathrm{~B}) ; \quad$ (C15-H15); $\quad$ (C10-C14); (C14-C17) and (C22-H22A) leading to stabilization of $33.27 \mathrm{~kJ} / \mathrm{mol}, 46.94 \mathrm{~kJ} / \mathrm{mol}, 61.61 \mathrm{~kJ} / \mathrm{mol}$, $118.16 \mathrm{~kJ} / \mathrm{mol}$ and $269.02 \mathrm{~kJ} / \mathrm{mol}$, respectively. This enhanced bond further conjugate with antibonding orbital of $\pi^{*}$ (C14-C15), which results in strong delocalization of $52.54 \mathrm{~kJ} / \mathrm{mol}$.

There is a very weak intramolecular $\mathrm{C}-\mathrm{H}$... S hydrogen bond exposed in the NBO analysis results shown in Table 4 caused by the interactions between the sulfur lone-pair LP(2) S2 and the antibonding orbital $\sigma^{*}(\mathrm{C} 17-\mathrm{H} 17 \mathrm{~B})$. The lone pair of N6 donates its electrons to the $\pi$-type antibonding orbital for (S2-C18). This interaction gives the strongest stabilization to the system of the title compound by $357.01 \mathrm{~kJ} / \mathrm{mol}$. In addition, the $\pi^{*}$ (C8-C9) NBO conjugates with respective bonds of $\pi^{*}(\mathrm{C} 10-\mathrm{C} 11)$ and $\pi^{*}(\mathrm{C} 12-\mathrm{C} 13)$ resulting in an enormous stabilization of $532.95 \mathrm{~kJ} / \mathrm{mol}$ and $830.56 \mathrm{~kJ} / \mathrm{mol}$, respectively.

\subsection{Atomic charge analysis}

In order to investigate the electron population of each atom of the title compound, the natural population analysis (NPA) atomic charges of the compound were calculated using the DFT/B3LYP method with the $6-311++\mathrm{G}(\mathrm{d}, \mathrm{p})$ basis set. The obtained results are given in Table 5. NPA charge plot has been shown in Fig. 4. The NPA analysis shows that the carbon atoms attached to hydrogen atoms are negative, whereas the carbon atoms $(\mathrm{C} 8, \mathrm{C} 11$,
C16) adjacent to the oxygen atoms of the chromene ring are positively charged. The oxygen atoms of chromene fragment and N6 atom of pyrrolidine ring have more negative atomic charges whereas all the hydrogen atoms have positive charges. The maximum positive atomic charge is obtained for C16 atom of carbonyl group when compared with all other atoms. This is due to the attachment of maximum negatively charged $\mathrm{O} 5$ atom.

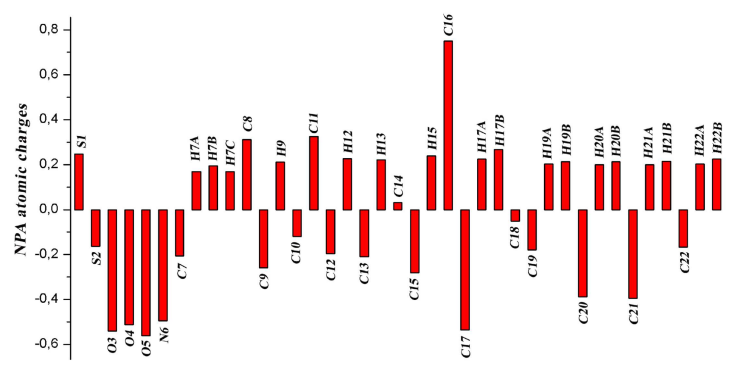

Fig. 4. Natural atomic charges of (6-Methoxy-2oxo-2H-chromen-4-yl)-methyl pyrrolidine-1carbodithioate.

\subsection{Electronic absorption spectra and frontier molecular orbital analysis}

The electronic absorption spectra of the title compound were computed using the TD-DFT method in the gas phase and the DMSO solvent (Fig. 5). The solvent effect was calculated using IEF-PCM method. For TD-DFT calculations, a theoretical absorption band was calculated at $242.43 \mathrm{~nm}(3.62 \mathrm{eV})$ with oscillator strength being 0.104 . The other absorption peak was calculated at $231.21 \mathrm{~nm}(5.36 \mathrm{eV})$ with oscillator strength being 0.114 . In addition to the calculations in gas phase, TD-DFT calculations of the title compound in DMSO solvent were performed at $352.01 \mathrm{~nm}$ $(3.52 \mathrm{eV})$ with oscillator strength being 0.127 and at $233.41 \mathrm{~nm}(5.31 \mathrm{eV})$ with oscillator strength being 0.208. According to the investigations on the frontier molecular orbital (FMO) energy levels of the title compound, we can find that the corresponding electronic transfers happened between the HOMO-1 and LUMO, HOMO-3 and LUMO +1 orbitals, respectively. 
Table 4. Selected second-order perturbation energies $\mathrm{E}^{(2)}$ associated with $\mathrm{i} \rightarrow \mathrm{j}$ delocalization in gas phase.

\begin{tabular}{|c|c|c|c|c|c|c|c|c|}
\hline Donor orbital (i) & Type & $\mathrm{ED} / \mathrm{e}$ & Acceptor orbital (j) & Type & $\mathrm{ED} / \mathrm{e}$ & $\mathrm{E}^{(2)}[\mathrm{kJ} / \mathrm{mol}]^{\mathrm{a}}$ & $E(j)-E(i)[a . u .]^{b}$ & $\mathrm{~F}(\mathrm{i}, \mathrm{j})[\text { a.u. }]^{\mathrm{c}}$ \\
\hline $\mathrm{S} 1-\mathrm{C} 17$ & $\sigma$ & 1.96731 & $\mathrm{C} 14-\mathrm{C} 15$ & $\pi *$ & 0.16017 & 13.08 & 0.78 & 0.046 \\
\hline $\mathrm{S} 1-\mathrm{C} 18$ & $\sigma$ & 1.97456 & $\mathrm{~N} 6-\mathrm{C} 22$ & $\sigma *$ & 0.03367 & 23.28 & 0.95 & 0.065 \\
\hline $\mathrm{S} 2-\mathrm{C} 18$ & $\sigma$ & 1.98622 & $\mathrm{~S} 2-\mathrm{C} 18$ & $\sigma *$ & 0.02661 & 19.18 & 0.22 & 0.033 \\
\hline S2-C18 & $\pi$ & 1.98142 & N6-C19 & $\sigma *$ & 0.03696 & 20.06 & 1.02 & 0.063 \\
\hline $\mathrm{O} 5-\mathrm{C} 16$ & $\pi$ & 1.97927 & $\mathrm{C} 14-\mathrm{C} 15$ & $\pi *$ & 0.16017 & 14.25 & 0.56 & 0.040 \\
\hline N6-C19 & $\sigma$ & 1.98300 & S2-C18 & $\pi *$ & 0.02661 & 15.92 & 1.02 & 0.056 \\
\hline $\mathrm{N} 6-\mathrm{C} 22$ & $\sigma$ & 1.98037 & $\mathrm{~S} 1-\mathrm{C} 18$ & $\sigma *$ & 0.11776 & 15.29 & 0.87 & 0.052 \\
\hline $\mathrm{N} 6-\mathrm{C} 22$ & $\sigma$ & 1.98037 & $\mathrm{C} 10-\mathrm{C} 14$ & $\sigma *$ & 0.03343 & 18.01 & 1.43 & 0.070 \\
\hline $\mathrm{N} 6-\mathrm{C} 22$ & $\sigma$ & 1.98037 & $\mathrm{C} 14-\mathrm{C} 15$ & $\pi *$ & 0.16017 & 14.71 & 0.91 & 0.052 \\
\hline $\mathrm{N} 6-\mathrm{C} 22$ & $\sigma$ & 1.98037 & $\mathrm{C} 14-\mathrm{C} 17$ & $\sigma *$ & 0.02814 & 31.35 & 1.60 & 0.098 \\
\hline $\mathrm{N} 6-\mathrm{C} 22$ & $\sigma$ & 1.98037 & $\mathrm{C} 15-\mathrm{H} 15$ & $\sigma *$ & 0.01325 & 16.17 & 1.32 & 0.064 \\
\hline N6-C22 & $\sigma$ & 1.98037 & $\mathrm{C} 22-\mathrm{H} 22 \mathrm{~A}$ & $\sigma *$ & 0.02002 & 98.68 & 5.65 & 0.326 \\
\hline $\mathrm{C} 7-\mathrm{H} 9$ & $\sigma$ & 1.99099 & $\mathrm{O} 3-\mathrm{C} 8$ & $\sigma *$ & 0.02948 & 14.50 & 0.89 & 0.050 \\
\hline $\mathrm{C} 8-\mathrm{C} 9$ & $\sigma$ & 1.97744 & $\mathrm{C} 9-\mathrm{C} 10$ & $\sigma *$ & 0.02110 & 14.96 & 1.26 & 0.060 \\
\hline $\mathrm{C} 8-\mathrm{C} 9$ & $\pi$ & 1.70329 & $\mathrm{C} 10-\mathrm{C} 11$ & $\pi *$ & 0.42279 & 73.94 & 0.31 & 0.069 \\
\hline $\mathrm{C} 8-\mathrm{C} 9$ & $\pi$ & 1.70329 & $\mathrm{C} 12-\mathrm{C} 13$ & $\pi *$ & 0.29806 & 69.93 & 0.31 & 0.064 \\
\hline $\mathrm{C} 8-\mathrm{C} 13$ & $\sigma$ & 1.97225 & $\mathrm{O} 3-\mathrm{C} 7$ & $\sigma *$ & 0.00895 & 13.04 & 0.99 & 0.050 \\
\hline $\mathrm{C} 8-\mathrm{C} 13$ & $\sigma$ & 1.97225 & $\mathrm{C} 8-\mathrm{C} 9$ & $\sigma *$ & 0.02751 & 17.09 & 1.27 & 0.064 \\
\hline C9-H9 & $\sigma$ & 1.97491 & $\mathrm{C} 8-\mathrm{C} 13$ & $\sigma *$ & 0.02300 & 16.55 & 1.09 & 0.059 \\
\hline C9-H9 & $\sigma$ & 1.97491 & $\mathrm{C} 10-\mathrm{C} 11$ & $\sigma *$ & 0.03420 & 16.80 & 1.09 & 0.059 \\
\hline $\mathrm{C} 9-\mathrm{C} 10$ & $\sigma$ & 1.96573 & $\mathrm{O} 3-\mathrm{C} 8$ & $\sigma *$ & 0.02948 & 17.89 & 1.05 & 0.060 \\
\hline $\mathrm{C} 9-\mathrm{C} 10$ & $\sigma$ & 1.96573 & $\mathrm{O} 4-\mathrm{C} 11$ & $\sigma *$ & 0.03285 & 15.88 & 1.04 & 0.056 \\
\hline C9-C10 & $\sigma$ & 1.96573 & $\mathrm{C} 8-\mathrm{C} 9$ & $\sigma *$ & 0.02751 & 14.25 & 1.26 & 0.059 \\
\hline $\mathrm{C} 9-\mathrm{C} 10$ & $\sigma$ & 1.96573 & $\mathrm{C} 10-\mathrm{C} 11$ & $\sigma *$ & 0.03420 & 15.88 & 1.25 & 0.061 \\
\hline $\mathrm{C} 9-\mathrm{C} 10$ & $\sigma$ & 1.96573 & $\mathrm{C} 10-\mathrm{C} 14$ & $\sigma *$ & 0.03343 & 13.00 & 1.40 & 0.059 \\
\hline $\mathrm{C} 10-\mathrm{C} 11$ & $\sigma$ & 1.97068 & $\mathrm{C} 9-\mathrm{C} 10$ & $\sigma *$ & 0.02110 & 15.00 & 1.25 & 0.060 \\
\hline $\mathrm{C} 10-\mathrm{C} 11$ & $\sigma$ & 1.97068 & $\mathrm{C} 11-\mathrm{C} 12$ & $\sigma *$ & 0.02153 & 18.09 & 1.25 & 0.066 \\
\hline $\mathrm{C} 10-\mathrm{C} 11$ & $\pi$ & 1.61973 & $\mathrm{C} 8-\mathrm{C} 9$ & $\pi *$ & 0.36558 & 74.48 & 0.29 & 0.064 \\
\hline $\mathrm{C} 10-\mathrm{C} 11$ & $\pi$ & 1.61973 & $\mathrm{C} 12-\mathrm{C} 13$ & $\pi *$ & 0.29806 & 71.68 & 0.30 & 0.066 \\
\hline $\mathrm{C} 10-\mathrm{C} 11$ & $\pi$ & 1.61973 & $\mathrm{C} 14-\mathrm{C} 15$ & $\pi *$ & 0.16017 & 42.21 & 0.45 & 0.064 \\
\hline $\mathrm{C} 10-\mathrm{C} 14$ & $\sigma$ & 1.96855 & $\mathrm{C} 9-\mathrm{C} 10$ & $\sigma *$ & 0.02110 & 15.29 & 1.22 & 0.060 \\
\hline $\mathrm{C} 11-\mathrm{C} 12$ & $\sigma$ & 1.97260 & $\mathrm{C} 10-\mathrm{C} 11$ & $\sigma *$ & 0.03420 & 18.93 & 1.26 & 0.068 \\
\hline $\mathrm{C} 12-\mathrm{H} 12$ & $\sigma$ & 1.97720 & $\mathrm{C} 8-\mathrm{C} 13$ & $\sigma *$ & 0.02300 & 14.67 & 1.07 & 0.055 \\
\hline $\mathrm{C} 12-\mathrm{H} 12$ & $\sigma$ & 1.97720 & $\mathrm{C} 10-\mathrm{C} 11$ & $\sigma *$ & 0.03420 & 17.84 & 1.08 & 0.061 \\
\hline $\mathrm{C} 12-\mathrm{C} 13$ & $\sigma$ & 1.97210 & $\mathrm{O} 3-\mathrm{C} 8$ & $\sigma *$ & 0.02948 & 13.50 & 1.07 & 0.052 \\
\hline $\mathrm{C} 12-\mathrm{C} 13$ & $\sigma$ & 1.97210 & $\mathrm{O} 4-\mathrm{C} 11$ & $\sigma *$ & 0.03285 & 15.34 & 1.06 & 0.056 \\
\hline $\mathrm{C} 12-\mathrm{C} 13$ & $\pi$ & 1.71752 & $\mathrm{C} 8-\mathrm{C} 9$ & $\pi *$ & 0.36558 & 80.67 & 0.28 & 0.067 \\
\hline $\mathrm{C} 12-\mathrm{C} 13$ & $\pi$ & 1.71752 & $\mathrm{C} 10-\mathrm{C} 11$ & $\pi *$ & 0.42279 & 75.53 & 0.31 & 0.069 \\
\hline C13-H13 & $\sigma$ & 1.97744 & $\mathrm{C} 8-\mathrm{C} 9$ & $\sigma *$ & 0.02751 & 17.93 & 1.09 & 0.061 \\
\hline $\mathrm{C} 13-\mathrm{H} 13$ & $\sigma$ & 1.97744 & $\mathrm{C} 11-\mathrm{C} 12$ & $\sigma *$ & 0.02153 & 13.91 & 1.06 & 0.053 \\
\hline $\mathrm{C} 14-\mathrm{C} 15$ & $\sigma$ & 1.97636 & C9-C10 & $\sigma *$ & 0.02110 & 13.33 & 1.29 & 0.057 \\
\hline $\mathrm{C} 14-\mathrm{C} 15$ & $\pi$ & 1.80442 & S1-C17 & $\sigma *$ & 0.02626 & 20.27 & 0.42 & 0.042 \\
\hline
\end{tabular}


Table 4. (Continuation) Selected second-order perturbation energies $E^{(2)}$ associated with $\mathrm{i} \rightarrow \mathrm{j}$ delocalization in gas phase.

\begin{tabular}{|c|c|c|c|c|c|c|c|c|}
\hline Donor orbital (i) & Type & $\mathrm{ED} / \mathrm{e}$ & Acceptor orbital (j) & Type & $\mathrm{ED} / \mathrm{e}$ & $\mathrm{E}^{(2)}[\mathrm{kJ} / \mathrm{mol}]^{\mathrm{a}}$ & $E(j)-E(i)$ [a.u.] $^{b}$ & $F(i, j)[a . u .]^{c}$ \\
\hline $\mathrm{C} 14-\mathrm{C} 15$ & $\pi$ & 1.80442 & $\mathrm{O} 5-\mathrm{C} 16$ & $\pi *$ & 0.28744 & 91.54 & 0.30 & 0.074 \\
\hline $\mathrm{C} 14-\mathrm{C} 15$ & $\pi$ & 1.80442 & $\mathrm{C} 10-\mathrm{C} 11$ & $\pi *$ & 0.42279 & 43.76 & 0.32 & 0.055 \\
\hline $\mathrm{C} 15-\mathrm{H} 15$ & $\sigma$ & 1.97420 & $\mathrm{O} 4-\mathrm{C} 16$ & $\sigma *$ & 0.12395 & 17.72 & 0.84 & 0.055 \\
\hline C15-H15 & $\sigma$ & 1.97420 & $\mathrm{C} 10-\mathrm{C} 14$ & $\sigma *$ & 0.03343 & 19.52 & 1.23 & 0.068 \\
\hline $\mathrm{C} 15-\mathrm{C} 16$ & $\sigma$ & 1.98160 & $\mathrm{C} 14-\mathrm{C} 15$ & $\sigma *$ & 0.01954 & 12.54 & 1.32 & 0.056 \\
\hline $\mathrm{C} 15-\mathrm{C} 16$ & $\sigma$ & 1.98160 & $\mathrm{C} 14-\mathrm{C} 17$ & $\sigma *$ & 0.02814 & 14.33 & 1.56 & 0.066 \\
\hline C17-H17B & $\sigma$ & 1.97909 & $\mathrm{C} 10-\mathrm{C} 14$ & $\sigma *$ & 0.03343 & 14.96 & 1.23 & 0.059 \\
\hline $\mathrm{C} 19-\mathrm{C} 20$ & $\sigma$ & 1.97909 & $\mathrm{~N} 6-\mathrm{C} 18$ & $\sigma *$ & 0.05998 & 15.04 & 1.09 & 0.057 \\
\hline $\mathrm{C} 21-\mathrm{C} 22$ & $\sigma$ & 1.98228 & $\mathrm{~N} 6-\mathrm{C} 18$ & $\sigma *$ & 0.05998 & 14.08 & 1.09 & 0.055 \\
\hline $\mathrm{C} 21-\mathrm{C} 22$ & $\sigma$ & 1.98228 & $\mathrm{C} 10-\mathrm{C} 14$ & $\sigma *$ & 0.03343 & 20.64 & 1.33 & 0.073 \\
\hline $\mathrm{C} 21-\mathrm{C} 22$ & $\sigma$ & 1.98228 & $\mathrm{C} 14-\mathrm{C} 15$ & $\pi *$ & 0.16017 & 25.53 & 0.81 & 0.065 \\
\hline $\mathrm{C} 21-\mathrm{C} 22$ & $\sigma$ & 1.98228 & $\mathrm{C} 14-\mathrm{C} 17$ & $\sigma *$ & 0.02814 & 41.00 & 1.49 & 0.108 \\
\hline $\mathrm{C} 21-\mathrm{C} 22$ & $\sigma$ & 1.98228 & $\mathrm{C} 22-\mathrm{H} 22 \mathrm{~A}$ & $\sigma *$ & 0.02002 & 100.57 & 5.55 & 0.326 \\
\hline $\mathrm{C} 22-\mathrm{H} 22 \mathrm{~A}$ & $\sigma$ & 1.98004 & $\mathrm{C} 10-\mathrm{C} 14$ & $\sigma *$ & 0.03343 & 18.93 & 1.22 & 0.067 \\
\hline $\mathrm{C} 22-\mathrm{H} 22 \mathrm{~A}$ & $\sigma$ & 1.98004 & $\mathrm{C} 14-\mathrm{C} 17$ & $\sigma *$ & 0.02814 & 38.58 & 1.39 & 0.101 \\
\hline $\mathrm{C} 22-\mathrm{H} 22 \mathrm{~A}$ & $\sigma$ & 1.98004 & C15-H15 & $\sigma *$ & 0.01325 & 14.79 & 1.12 & 0.056 \\
\hline $\mathrm{C} 22-\mathrm{H} 22 \mathrm{~A}$ & $\sigma$ & 1.98004 & $\mathrm{C} 21-\mathrm{H} 21 \mathrm{~A}$ & $\sigma *$ & 0.01457 & 21.69 & 0.94 & 0.063 \\
\hline $\mathrm{C} 22-\mathrm{H} 22 \mathrm{~A}$ & $\sigma$ & 1.98004 & $\mathrm{C} 21-\mathrm{C} 22$ & $\sigma *$ & 0.01296 & 15.46 & 2.76 & 0.090 \\
\hline $\mathrm{C} 22-\mathrm{H} 22 \mathrm{~A}$ & $\sigma$ & 1.98004 & $\mathrm{C} 22-\mathrm{H} 22 \mathrm{~A}$ & $\sigma *$ & 0.02002 & 66.54 & 5.44 & 0.263 \\
\hline $\mathrm{C} 22-\mathrm{H} 22 \mathrm{~A}$ & $\sigma$ & 1.98004 & $\mathrm{C} 22-\mathrm{H} 22 \mathrm{~B}$ & $\sigma *$ & 0.02002 & 51.99 & 2.82 & 0.168 \\
\hline $\mathrm{C} 22-\mathrm{H} 22 \mathrm{~B}$ & $\sigma$ & 1.98156 & $\mathrm{C} 10-\mathrm{C} 14$ & $\sigma *$ & 0.03343 & 61.61 & 1.21 & 0.120 \\
\hline $\mathrm{C} 22-\mathrm{H} 22 \mathrm{~B}$ & $\sigma$ & 1.98156 & $\mathrm{C} 14-\mathrm{C} 15$ & $\pi *$ & 0.16017 & 52.54 & 0.70 & 0.087 \\
\hline $\mathrm{C} 22-\mathrm{H} 22 \mathrm{~B}$ & $\sigma$ & 1.98156 & $\mathrm{C} 14-\mathrm{C} 17$ & $\sigma *$ & 0.02814 & 118.16 & 1.38 & 0.177 \\
\hline $\mathrm{C} 22-\mathrm{H} 22 \mathrm{~B}$ & $\sigma$ & 1.98156 & $\mathrm{C} 15-\mathrm{H} 15$ & $\sigma *$ & 0.01325 & 46.94 & 1.11 & 0.100 \\
\hline $\mathrm{C} 22-\mathrm{H} 22 \mathrm{~B}$ & $\sigma$ & 1.98156 & $\mathrm{C} 22-\mathrm{H} 22 \mathrm{~A}$ & $\sigma *$ & 0.02002 & 269.02 & 5.44 & 0.528 \\
\hline $\mathrm{C} 22-\mathrm{H} 22 \mathrm{~B}$ & $\sigma$ & 1.98156 & $\mathrm{C} 22-\mathrm{H} 22 \mathrm{~B}$ & $\sigma *$ & 0.01560 & 33.27 & 2.82 & 0.134 \\
\hline S1 & $\mathrm{LP}(1)$ & 1.97272 & $\mathrm{~S} 2-\mathrm{C} 18$ & $\pi *$ & 0.02661 & 28.34 & 0.93 & 0.071 \\
\hline S1 & $\mathrm{LP}(2)$ & 1.81217 & $\mathrm{~S} 2-\mathrm{C} 18$ & $\sigma *$ & 0.50942 & 126.61 & 0.18 & 0.072 \\
\hline S2 & $\mathrm{LP}(1)$ & 1.97823 & $\mathrm{~S} 1-\mathrm{C} 18$ & $\sigma *$ & 0.11776 & 19.35 & 0.86 & 0.058 \\
\hline S2 & $\mathrm{LP}(1)$ & 1.97823 & N6-C18 & $\sigma *$ & 0.05998 & 13.83 & 1.18 & 0.056 \\
\hline S2 & $\mathrm{LP}(2)$ & 1.82347 & $\mathrm{~S} 1-\mathrm{C} 18$ & $\sigma *$ & 0.11776 & 69.05 & 0.35 & 0.068 \\
\hline S2 & $\mathrm{LP}(2)$ & 1.82347 & N6-C18 & $\sigma *$ & 0.05998 & 46.73 & 0.67 & 0.080 \\
\hline S2 & $\mathrm{LP}(2)$ & 1.82347 & C17-H17B & $\sigma *$ & 0.03283 & 16.63 & 0.61 & 0.046 \\
\hline $\mathrm{O} 3$ & $\mathrm{LP}(1)$ & 1.96313 & $\mathrm{C} 8-\mathrm{C} 9$ & $\sigma *$ & 0.02751 & 29.05 & 1.11 & 0.079 \\
\hline $\mathrm{O} 3$ & $\mathrm{LP}(2)$ & 1.84590 & $\mathrm{C} 7-\mathrm{H} 7 \mathrm{~A}$ & $\sigma *$ & 0.01902 & 23.36 & 0.69 & 0.057 \\
\hline $\mathrm{O} 3$ & $\mathrm{LP}(2)$ & 1.84590 & $\mathrm{C} 7-\mathrm{H} 7 \mathrm{C}$ & $\sigma *$ & 0.01908 & 23.53 & 0.69 & 0.058 \\
\hline $\mathrm{O} 3$ & $\mathrm{LP}(2)$ & 1.84590 & $\mathrm{C} 8-\mathrm{C} 9$ & $\pi *$ & 0.36558 & 125.23 & 0.34 & 0.095 \\
\hline $\mathrm{O} 4$ & $\mathrm{LP}(1)$ & 1.96311 & $\mathrm{C} 10-\mathrm{C} 11$ & $\sigma *$ & 0.03420 & 26.54 & 1.09 & 0.074 \\
\hline $\mathrm{O} 4$ & $\mathrm{LP}(1)$ & 1.96311 & $\mathrm{C} 15-\mathrm{C} 16$ & $\sigma *$ & 0.05477 & 18.76 & 1.00 & 0.060 \\
\hline $\mathrm{O} 4$ & $\mathrm{LP}(2)$ & 1.74309 & $\mathrm{O} 5-\mathrm{C} 16$ & $\pi *$ & 0.28744 & 146.13 & 0.35 & 0.100 \\
\hline
\end{tabular}


Table 4. (Continuation) Selected second-order perturbation energies $E^{(2)}$ associated with $\mathrm{i} \rightarrow \mathrm{j}$ delocalization in gas phase.

\begin{tabular}{|c|c|c|c|c|c|c|c|c|}
\hline Donor orbital (i) & Type & $\mathrm{ED} / \mathrm{e}$ & Acceptor orbital (j) & Type & $\mathrm{ED} / \mathrm{e}$ & $\mathrm{E}^{(2)}[\mathrm{kJ} / \mathrm{mol}]^{\mathrm{a}}$ & $E(j)-E(i)$ [a.u.] ${ }^{b}$ & $F(i, j)[a . u .]^{c}$ \\
\hline $\mathrm{O} 4$ & $\mathrm{LP}(2)$ & 1.74309 & $\mathrm{C} 10-\mathrm{C} 11$ & $\pi *$ & 0.42279 & 113.65 & 0.37 & 0.094 \\
\hline O5 & $\mathrm{LP}(2)$ & 1.83314 & $\mathrm{O} 4-\mathrm{C} 16$ & $\sigma *$ & 0.12395 & 156.33 & 0.57 & 0.131 \\
\hline O5 & $\mathrm{LP}(2)$ & 1.83314 & $\mathrm{C} 15-\mathrm{C} 16$ & $\sigma *$ & 0.05477 & 66.75 & 0.70 & 0.097 \\
\hline N6 & $\mathrm{LP}(1)$ & 1.61189 & $\mathrm{~S} 2-\mathrm{C} 18$ & $\sigma *$ & 0.50942 & 357.01 & 0.19 & 0.118 \\
\hline N6 & $\mathrm{LP}(1)$ & 1.61189 & C19-H19A & $\sigma *$ & 0.02121 & 23.61 & 0.65 & 0.060 \\
\hline N6 & $\mathrm{LP}(1)$ & 1.61189 & C19-H19B & $\sigma *$ & 0.01621 & 13.54 & 0.67 & 0.046 \\
\hline $\mathrm{O} 4-\mathrm{C} 16$ & $\sigma *$ & 0.12395 & $\mathrm{O} 4-\mathrm{C} 11$ & $\sigma *$ & 0.03285 & 114.19 & 0.02 & 0.080 \\
\hline $\mathrm{O} 5-\mathrm{C} 16$ & $\pi *$ & 0.28744 & $\mathrm{C} 14-\mathrm{C} 15$ & $\pi *$ & 0.16017 & 31.39 & 0.17 & 0.067 \\
\hline $\mathrm{C} 8-\mathrm{C} 9$ & $\pi *$ & 0.36558 & $\mathrm{C} 10-\mathrm{C} 11$ & $\pi *$ & 0.42279 & 532.95 & 0.02 & 0.077 \\
\hline $\mathrm{C} 8-\mathrm{C} 9$ & $\pi *$ & 0.36558 & $\mathrm{C} 12-\mathrm{C} 13$ & $\pi *$ & 0.29806 & 830.56 & 0.01 & 0.082 \\
\hline $\mathrm{C} 10-\mathrm{C} 11$ & $\pi *$ & 0.42279 & $\mathrm{C} 14-\mathrm{C} 15$ & $\pi *$ & 0.16017 & 135.68 & 0.14 & 0.113 \\
\hline $\mathrm{C} 10-\mathrm{C} 11$ & $\pi *$ & 0.42279 & $\mathrm{C} 14-\mathrm{C} 17$ & $\sigma *$ & 0.02814 & 14.08 & 0.83 & 0.099 \\
\hline $\mathrm{C} 10-\mathrm{C} 11$ & $\pi *$ & 0.42279 & $\mathrm{C} 22-\mathrm{H} 22 \mathrm{~A}$ & $\sigma *$ & 0.02002 & 18.68 & 4.89 & 0.280 \\
\hline $\mathrm{C} 14-\mathrm{C} 15$ & $\pi *$ & 0.16017 & $\mathrm{C} 10-\mathrm{C} 14$ & $\sigma *$ & 0.03343 & 24.28 & 0.52 & 0.158 \\
\hline $\mathrm{C} 14-\mathrm{C} 15$ & $\pi *$ & 0.16017 & $\mathrm{C} 14-\mathrm{C} 17$ & $\sigma *$ & 0.02814 & 36.65 & 0.69 & 0.226 \\
\hline $\mathrm{C} 14-\mathrm{C} 15$ & $\pi *$ & 0.16017 & $\mathrm{C} 15-\mathrm{H} 15$ & $\sigma *$ & 0.01325 & 14.42 & 0.41 & 0.114 \\
\hline C14-C15 & $\pi *$ & 0.16017 & $\mathrm{C} 22-\mathrm{H} 22 \mathrm{~A}$ & $\sigma *$ & 0.02002 & 60.61 & 4.74 & 0.780 \\
\hline
\end{tabular}

${ }^{\mathrm{a}} \mathrm{E}^{(2)}$ energy of hyper conjugative interactions

${ }^{b}$ Energy difference between donor and acceptor $i$ and $j$ NBO orbitals

${ }^{\mathrm{c}} \mathrm{F}_{\mathrm{ij}}$ is the Fock matrix element between $\mathrm{i}$ and $\mathrm{j}$ NBO orbitals

The FMO plays an important role in the electric and optical properties, as well as in UV-Vis spectra and chemical reactions [71, 72]. Fig. 6 shows the distributions and energy levels of the HOMO-1, HOMO, LUMO and LUMO +1 orbitals calculated at the B3LYP/6-311++G(d,p) level for the title molecule. As can be seen from Fig. 6, both for the HOMO and HOMO-1, the electrons are delocalized on the sulfur atoms of the pyrrolidine-1carbodithioate. For the LUMO and LUMO+1, the electrons are mainly delocalized on the 2-oxo- $2 \mathrm{H}-$ chromen ring, $\mathrm{C} 14-\mathrm{C} 17$ bond and $\mathrm{S} 1$ atom. The value of the energy separation between the HOMO and LUMO is $1.42 \mathrm{eV}$. Considering the chemical hardness, small HOMO-LUMO gap $\left(\Delta \mathrm{E}_{\mathrm{H}-\mathrm{L}}\right)$ means a soft molecule and large $\Delta \mathrm{E}_{\mathrm{H}-\mathrm{L}}$ means a hard molecule. One can also relate the stability of the molecule to hardness, which means that the molecule with the least $\Delta \mathrm{E}_{\mathrm{H}-\mathrm{L}}$ is more reactive and less stable [73]. The $\eta$ and $S$ can be calculated using the HOMO and LUMO energy values for a molecule as follows: $\eta=\left(E_{\mathrm{LUMO}}-\mathrm{E}_{\mathrm{HOMO}}\right) / 2$ and $S=1 / 2 \eta[60]$, where $E_{\text {LUMO }}$ and $E_{\text {HOMO }}$ are LUMO and HOMO energies, respectively. The calculated values of $\eta$ and $S$ for the title compound are $0.71 \mathrm{eV}$ and $0.70 \mathrm{eV}^{-1}$, respectively.

\subsection{Molecular electrostatic potential}

Molecular electrostatic potential (MEP) mapping is very useful for understanding the sites for electrophilic attack and nucleophilic reactions as well as hydrogen bonding interactions [74]. Red-electron rich or partially negative charge regions of MEP are related to electrophilic reactivity and the blue-electron deficient or partially positive charge regions of MEP are related to nucleophilic reactivity shown in Fig. 7. The MEP clearly indicates that the electron rich centres were found around the $\mathrm{O} 3, \mathrm{O} 5$ and $\mathrm{S} 2$ atoms. The negative $\mathrm{V}(\mathrm{r})$ values are -0.023 a.u. for $\mathrm{O} 3$ atom, -0.103 a.u. for $\mathrm{O} 5$ and -0.035 a.u. for $\mathrm{S} 2$ atom. 
Table 5. Natural atomic charges (e) of (6-Methoxy-2oxo-2H-chromen-4-yl)-methyl pyrrolidine-1carbodithioate.

\begin{tabular}{cccccc}
\hline Atom & B3LYP & Atom & B3LYP & Atom & B3LYP \\
\hline \hline S1 & 0.24719 & C10 & -0.11967 & C18 & -0.05156 \\
S2 & -0.16350 & C11 & 0.32460 & C19 & -0.17943 \\
O3 & -0.54097 & C12 & -0.19651 & H19A & 0.20289 \\
O4 & -0.51251 & H12 & 0.22618 & H19B & 0.21295 \\
O5 & -0.56201 & C13 & -0.21046 & C20 & -0.38867 \\
N6 & -0.49501 & H13 & 0.22257 & H20A & 0.19988 \\
C7 & -0.20596 & C14 & 0.03099 & H20B & 0.21342 \\
H7A & 0.16955 & C15 & -0.28039 & C21 & -0.39439 \\
H7B & 0.19436 & H15 & 0.23948 & H21A & 0.20043 \\
H7C & 0.16919 & C16 & 0.75023 & H21B & 0.21463 \\
C8 & 0.31283 & C17 & -0.53537 & C22 & -0.16780 \\
C9 & -0.25921 & H17A & 0.22481 & H22A & 0.20388 \\
H9 & 0.21104 & H17B & 0.26817 & H22B & 0.22427
\end{tabular}

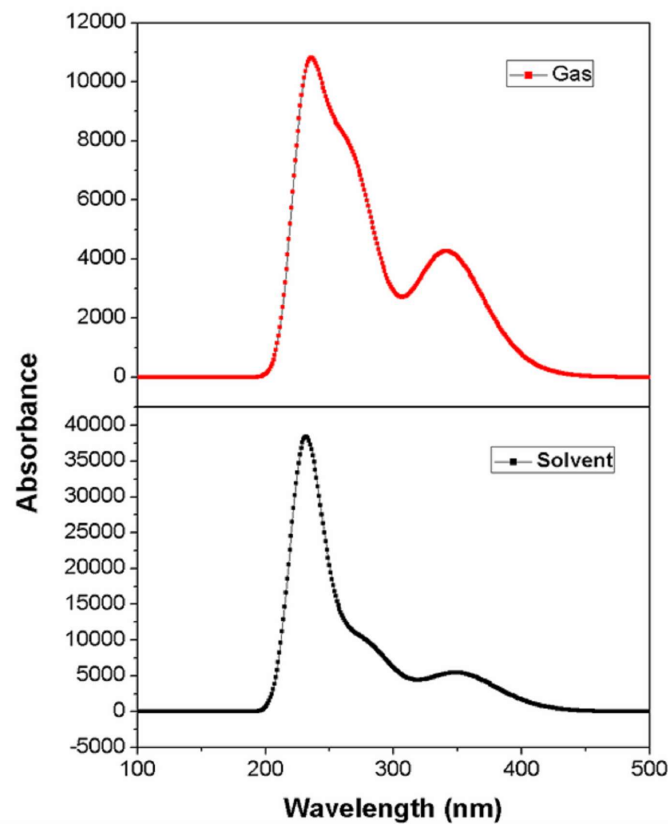

Fig. 5. Theoretical UV-Vis spectra of (6-Methoxy2-oxo-2H-chromen-4-yl)-methyl pyrrolidine-1carbodithioate. gas (top) and DSMO (bottom).

Thus, it could be predicted that an electrophile would preferentially attack the title molecule at O5 atom. On the other hand, a maximum positive region is localized on the methyl nearby with a value of +0.069 a.u. indicating a possible site for
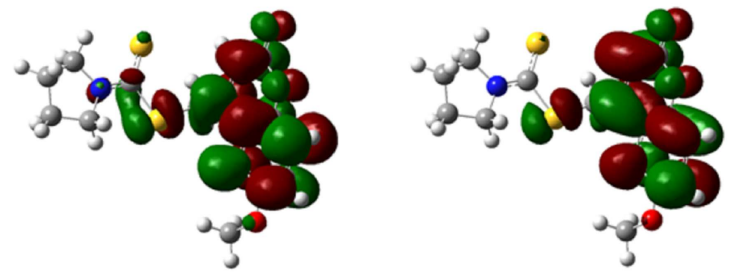

LUMO+1 $(-4.48 \mathrm{eV})$

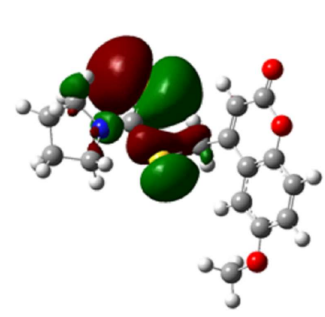

HOMO-1 (-7.52 eV)

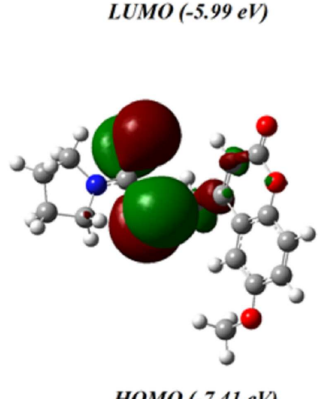

Fig. 6. Molecular orbital surfaces and energy levels of (6-Methoxy-2-oxo-2H-chromen-4-yl)methyl pyrrolidine-1-carbodithioate.

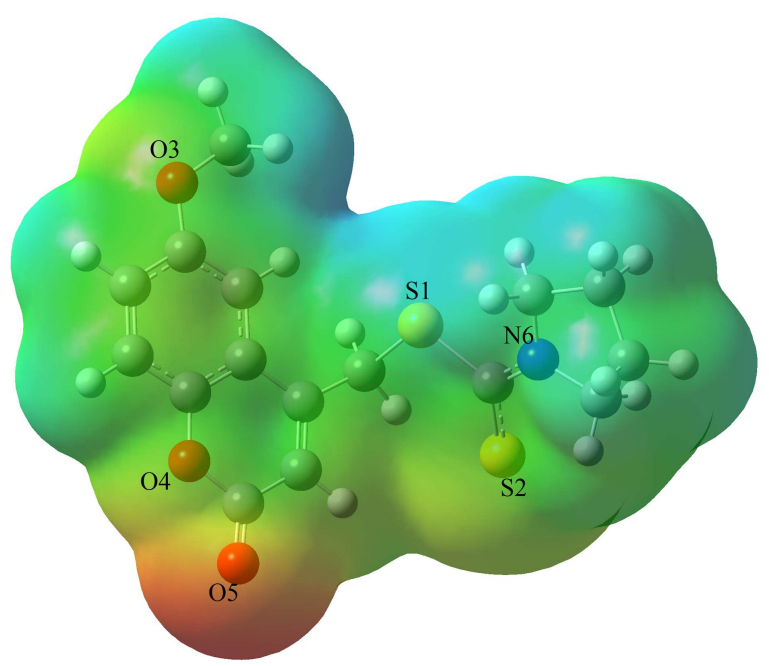

Fig. 7. The total electron density mapped with electrostatic potential of the title compound.

nucleophilic attack. So, the MEP surfaces clearly indicate that positive potential sites are around methylene and methyl hydrogen atoms. These sites give information that the compound can have metallic bonding and intermolecular interactions [73]. 


\subsection{Non-linear optical properties}

Nonlinear optics (NLO) is at the forefront of current research because of its importance in providing the key functions of frequency shifting, optical switching, optical modulation, optical logic, and optical memory for emerging technologies in areas such as telecommunications, signal processing, and optical interconnections [75, 76].

The dipole moment $(\mu)$, polarizability $(\alpha)$ and first hyperpolarizbility $(\beta)$ values of the title molecule were computed at the B3LYP/6$311++\mathrm{G}(\mathrm{d}, \mathrm{p})$ level using the Gaussian 09W program package. Calculations of the polar properties ( $\alpha$ and $\beta$ ) from the Gaussian output have been explained in detail previously [77], and DFT has been used extensively as an effective method to investigate organic NLO materials [78, 79].

The calculated values of $\mu, \alpha$ and $\beta$ are 9.007 Debye, $38.299 \AA^{3}$ and 4.868 esu for the title compound. Urea is used as one of the prototypical molecules in the study of NLO properties of molecular systems. Therefore, it has been used frequently as a threshold value for comparative purposes [78]. The values of $\alpha$ and $\beta$ of the title compound are greater than those of urea (the $\alpha$ and $\beta$ of urea are $5.042 \AA^{3}$ and $0.78 \times 10^{-30}$ esu obtained using the B3LYP/6$311++G(d, p)$ method) [22]. Theoretically, the $\beta$ value of the title compound is of 6.24 times magnitude of urea. When we compare it with the similar compounds in the literature, the calculated value of $\beta$ of the title compound is smaller than those of 9-methoxy-2H-furo3,2-gchromen2-one $\left(\beta=5.2983 \times 10^{-30}\right.$ esu calculated with B3LYP/6-311++G(d,p) method) [80] and 6-phenylazo-3-(p-tolyl)-2H-chromen-2-one $(\beta=$ $34.528 \times 10^{-30}$ esu calculated with B3LYP/6$311++\mathrm{G}(\mathrm{d}, \mathrm{p})$ method) [81]. According to the magnitude of $\beta$, the title coumarin compound may be a potential applicant in the development of NLO materials.

\subsection{Thermodynamic properties}

The standard thermodynamic functions: entropy $\left(\mathrm{S}_{\mathrm{m}}^{0}\right)$, heat capacity $\left(\mathrm{C}_{\mathrm{p}, \mathrm{m}}^{0}\right)$ and enthalpy
$\left(\mathrm{H}_{\mathrm{m}}^{0}\right)$ were obtained on the basis of B3LYP/6$311++\mathrm{G}(\mathrm{d}, \mathrm{p})$ vibrational analysis and statistical thermodynamics and listed in Table 6. The Table shows that the $\mathrm{S}_{\mathrm{m}}^{0}, \mathrm{C}_{\mathrm{p}, \mathrm{m}}^{0}$ and $\mathrm{H}_{\mathrm{m}}^{0}$ increase at any temperature from $200.00 \mathrm{~K}$ to $600.00 \mathrm{~K}$, because the intensities of the molecular vibration increase with the increasing temperature.

The correlations equations between these thermodynamic properties and temperatures $\mathrm{T}$ are as follows:

$$
\begin{gathered}
C_{p, m}^{0}=-11.97047+1.36407 T-6.32498 \times 10^{-4} T^{2} \\
\quad\left(R^{2}=0.99978\right) \\
S_{m}^{0}=290.75334+1.33432 T-2.92022 \times 10^{-5} T^{2} \\
\quad\left(R^{2}=1\right)
\end{gathered}
$$

$H_{m}^{0}=-6.01208+0.08769 T+4.33528 \times 10^{-4} T^{2}$

$$
\left(R^{2}=0.99995\right)
$$

These equations will be helpful for the further studies of the title compound $[82,83]$.

Table 6. Thermodynamic properties at different temperatures at B3LYP/6-311++G(d,p) level.

\begin{tabular}{cccc}
\hline $\begin{array}{c}\mathrm{T} \\
{[\mathrm{K}]}\end{array}$ & $\begin{array}{c}\mathrm{H}_{\mathrm{m}}^{0} \\
{\left[\mathrm{~kJ} \cdot \mathrm{mol}^{-1}\right]}\end{array}$ & $\begin{array}{c}\mathrm{C}_{\mathrm{p}, \mathrm{m}}^{0} \\
{\left[\mathrm{~J} \cdot \mathrm{mol}^{-1} \cdot \mathrm{K}^{-1}\right]}\end{array}$ & $\begin{array}{c}\mathrm{S}_{\mathrm{m}}^{0} \\
{\left[\mathrm{~J} \cdot \mathrm{mol}^{-1} \cdot \mathrm{K}^{-1}\right]}\end{array}$ \\
\hline \hline 200 & 29.30 & 237.84 & 545.94 \\
250 & 42.84 & 287.79 & 606.22 \\
300 & 58.89 & 338.28 & 664.70 \\
350 & 77.45 & 387.27 & 721.80 \\
400 & 98.39 & 433.17 & 777.68 \\
450 & 121.55 & 475.18 & 832.15 \\
500 & 146.67 & 513.09 & 885.07 \\
550 & 173.63 & 547.07 & 936.40 \\
600 & 202.18 & 577.55 & 986.06 \\
\hline
\end{tabular}

\section{Conclusions}

In this study, we have calculated the geometric parameters, vibrational frequencies and chemical shifts of (6-Methoxy-2-oxo-2H-chromen-4yl)-methyl pyrrolidine-1-carbodithioate using 
the DFT/B3LYP and HF methods in conjunction with the $6-311++\mathrm{G}(\mathrm{d}, \mathrm{p})$ basis set. The comparisons between the calculated results and the X-ray experimental data show that HF method is better than B3LYP method in evaluating bond lengths. However, the B3LYP method seems to be more appropriate than HF method for predicting the bond angles and 3D geometry of the title compound. The vibrational frequencies are exactly assigned to its molecular structure with the aid of the theoretical calculations at B3LYP/6-311++G(d,p) and $\mathrm{HF} / 6-311++\mathrm{G}(\mathrm{d}, \mathrm{p})$ levels, in which the experimental and theoretical results support each other. Furthermore, the calculated electronic absorption wavelengths and ${ }^{1} \mathrm{H}$ and ${ }^{13} \mathrm{C}$ NMR chemical shift values of the title compound in gas phase and solvent media can be built into the database for other chromen and pyrrolidine derivatives. It will be helpful for the design and synthesis of new materials. The stabilization energies were obtained from the second-order perturbation theory. The NBO analysis revealed that the $\pi^{*} \rightarrow \pi^{*}$ interactions give the strongest stabilization to the system. The correlations between the statistical thermodynamic properties (enthalpy, entropy, heat capacity) and temperature were also obtained. The calculated first order hyperpolarizability of the title compound was 6.24 times greater than that of urea.

\section{References}

[1] Lisgarten J.N., Potter B.S., Aymami J., OKetch-Rabah H., Palmer, R.A., J. Chem. Crystallogr., 33 (2003), 149.

[2] Sharma P.N., Shoeb A., Kapil R.S., Popli S.P., Indian J. Chem. B, 17 (1979), 299.

[3] Sharma P.N., Shoeb A., Kapil R.S., Popli S.P., Indian J. Chem. B, 19 (1980), 938.

[4] Sharma P.N., Shoeb A., Kapil R.S., Popli S.P., Phytochemistry, 20 (1981), 335.

[5] Enraf-Nonius CAD-4 Express '88 Software, EnrafNonius: Delft, Holland, 1988.

[6] North A.C.T., Philips D.C., Mathews F.S., Acta Crystallogr. A, 24 (1968), 351.

[7] Jones G., Jackson W.R., Choi C., Bergmark W.R., J. Phys. Chem., 89 (1985), 294.

[8] Trenor S.R., Shultz A.R., Love B.J., Long T.E., Chem. Rev., 104 (2004), 3059.

[9] Hung T.T., LU Y.J., LiaO W.Y., Huang C.L., IEEE T. Magn., 43 (2007), 867.
[10] Kumar K.M., Kour D., Kapoor K., MahaBaleshwaraiah N.M., Kotresh O., Gupta V.K., KANT R., Acta Crystallogr. E, 68 (2012), o878.

[11] Hault J.R.S., Paya M., Vascul. Pharmacol., 27 (1996), 713.

[12] Riveiro M.E., Kimpe N.D., Moglioni A., VAzQuez R., Monczor F., Shayo C., Davio C., Curr. Med. Chem., 17 (2010), 1325.

[13] Sivaguru P., Sandhiya R., Adhiyaman M., Lalitha A., Tetrahedron Lett., 57 (23) (2016), 2496.

[14] Zhang Y., Guo Z.J., You X.Z., J. Am. Chem. Soc., 123 (2001), 9378.

[15] Proft de F., Geerlings P., Chem. Rev., 101 (2001), 1451.

[16] Bingöl Alpaslan Y., Gökce H., Alpaslan G., MACIT M., J. Mol. Struct., 1097 (2015), 171.

[17] TANAK H., ERŞAhin F., KÖYSAL Y., AĞAR E., IşıK Ş., YAVuz M., J. Mol. Model., 15 (2009), 1281.

[18] Mahabaleshwaraiah N.M., Kumar K.M., Kotresh O., Al-Eryani W.F.A., DevarajeGOWDA H.C., Acta Crystallogr. E, 68 (2012), o1566.

[19] Frisch M.J., Trucks G.W., SChlegel H.B., Gaussian 09, Revision C.01, Gaussian, Inc.: Wallingford, CT, 2009.

[20] Dennington R., Keith T., Millam J., GaussView, Version 5, Semichem Inc.: Shawnee Mission, KS, 2009.

[21] Wolinski K., Hinton J.F., Pulay P., J. Am. Chem. Soc., 112 (1990), 8251

[22] Toy M., TANaK H., Spectrochim. Acta A, 152 (2016), 530.

[23] Cancčs E., Mennucci B., Tomasi J., J. Chem. Phys., 107 (1997), 3032.

[24] Phakhodee W., Laphookhieo S., Prior T.J., RUJiWatra A., Acta Crystallogr. E, 68 (2012), o3421.

[25] Devarajegowda H.C., Kumar K.M., Seenivasa S., Arunkashi H.K., Kotresh O., Acta Crystallogr. E, 69 (2013), o192.

[26] Sinha S., Osman H., Wahab H.A., HemamaLINI M., FUn H.K., Acta Crystallogr. E, 67 (2011), o3457.

[27] Tanak H., Agar A.A., BÜYÜKgüngör O., Spectrochim. Acta A, 87 (2012), 15.

[28] Agar A.A., Tanak H., Yavuz M., Mol. Phys., 108 (2010), 1759.

[29] Teimouri A., Emami M., Chermahini A.N., DabBagh H.A., Spectrochim. Acta A, 71 (2009), 1749.

[30] Dereli Ö., Bahçeli S., Abbas A., Naseer M.M., Monatsh. Chem., 146 (2015), 1473.

[31] Silverstein R.M., Basseler G.C., Morill C., Spectroscopic Identification of Organic Compounds, Wiley, New York, 1981.

[32] Rahman T.U., Arfan M., Mahmood T., LIAQAT W., Gilani M.A., UdDi G., LudWig R., ZaMAN K., ChOUdHaRY M.I., KHATTAK K.F., AYUB K., Spectrochim. Acta A, 146 (2015), 24.

[33] Singh R.N., Prasad S.C., Spectrochim. Acta A, 34 (1974), 39. 
[34] Sarikaya K.E., Dereli Ö., J. Mol. Struct., 1052 (2013), 214.

[35] Babu P.C., Sundaraganesan N., Dereli O., TURKKAN E., Spectrochim. Acta A, 79 (2011), 562.

[36] Subramanian N., Sundaraganesan N., Dereli O., TurkKan E., Spectrochim. Acta A, 83 (2011), 165.

[37] Kalaichelvan S., Sundaraganesan N., Dereli O., SAYIN U., Spectrochim. Acta A, 85 (2012), 189.

[38] Litivinov G., Proceedings of the XIII International Conference on Raman Spectroscopy, Wurzburg, Germany, 1992.

[39] El-Gogary T.M., Soliman M.S., Spectrochim. Acta A, 57 (2001), 2647.

[40] AL-SAADi A.A., LAANE J., J. Mol. Struct., 830 (2007), 46.

[41] Parlak C., J. Mol. Struct., 966 (2010), 1.

[42] Sundaraganesan N., AnAND B., Meganathan C., Dominic Joshua B., SAlEEM H., Spectrochim. Acta A, 69 (2008), 198.

[43] Arjunan V., Santhanam R., Sakiladevi S., Marchewka M.K., Mohan S., J. Mol. Struct., 1037 (2013), 305.

[44] Moghaddam F.M., Foroushani B.K., J. Mol. Struct., 1065 (2014), 235.

[45] Sajan D., Erdogdu Y., Reshmy R., Dereli Ö., Kurien Thomas K., Hubert Joe I., Spectrochim. Acta A, 82 (2011), 118.

[46] SRi N.U., Chaitanya K., Prasad M.V.S., VeeraIAH V., Veeraiah A., Spectrochim. Acta A, 97 (2012), 728.

[47] Prabhua T., Periandy S., Ramalingam S., Spectrochim. Acta A, 83 (2011), 8.

[48] Tecklenburg M.M.J., Kosnak D.J., BhatnaGAR A., Mohanty D.K., J. Raman Spectrosc., 28 (1997), 755.

[49] Pajazk J., Rospenk M., Ramaekers R., Maes G., GŁowiak T., Sobczyk L., Chem. Phys., 278 (2002), 89.

[50] Arivazhagan M., Krishnakumar V., JohnXAVIER R., Ilango V., Balachandran K., Spectrochim. Acta A, 72 (2009), 941.

[51] Rahman T.U., Arfan M., Mahmood T., LIAQAT W., Gilani M.A., UdDin G., LUdWIng R., Zaman K., Choudhary M.I., KhatTAK K.F., Ayub K., Spectrochim. Acta A, 146 (2015), 24.

[52] Silverstein R.M., Webstor F.X., Spectrometric Identification of Organic Compounds, $6^{\text {th }}$ ed., John Willey \& Sons, New York, 1998.

[53] Bellamy L.J., The Infrared Spectra of Complex Molecules, Chapman and Hall, London, 1975.

[54] Rao C.N., Chemical Application of Infrared Spectroscopy, Academic Press, New York, 1963.
[55] Thanikachalam V., Periyanayagasamy V., Jayabharathi J., Manikandan G., Saleem H., SubashCHANDrabose S., ERdogdu Y., Spectrochim. Acta A, 87 (2012), 86.

[56] Mani P., Umamaheswari H., Dominic Joshua B., Sundaraganesan N., J. Mol. Struct., 868 (2008), 44.

[57] KAKKAR R., DUA A., ZAIDI S., Spectrochim. Acta A, 68 (2007), 1362.

[58] TANAK H., J. Mol. Struct., 1090 (2015), 86.

[59] Tanak H., Agar A.A., BÜYÜKGÜngÖr O., Spectrochim. Acta A, 118 (2014), 672.

[60] Rajesh P., Gunasekaran S., GnAnASAMbanDAN T., Seshadri S., Spectrochim. Acta A, 137 (2015), 1184.

[61] Ramya T., Gunasekaran S., Ramkumaar G.R., Spectrochim. Acta A, 149 (2015), 132.

[62] Krishnan G.K., Sivakumar R., ThanikachaLaM V., Saleem H., Arockia Doss M., Spectrochim. Acta A, 144 (2015), 29.

[63] Erdogdu Y., Saglam S., Dereli Ö., Opt. Spectrosc.,+ 119 (2015), 441.

[64] Ramya T., Gunasekaran S., Ramkumaar G.R., Spectrochim. Acta A, 149 (2015), 132.

[65] Pisani L., Catto M., Nicolotti O., Grossi G., Braccio di M., Soto-Otero R., MEndeZAlvarez E., Stefanachi A., Gadaleta D., CArotti A., Eur. J. Med. Chem., 70 (2013), 723.

[66] James C., Amal Raj A., Reghunathan R., HuBERT JoE I., JAYAKUMAR V.S., J. Raman Spectrosc., 37 (2006), 1381.

[67] LiU J.N., Chen Z.R., YuAn S.F., ZheJiAng J., J. Zhejiang Univ.-Sc. B, 6 (2005), 584.

[68] Muthu S., Prasath M., Spectrochim. Acta A, 115 (2013),789.

[69] Schwenke D.W., Truhlar D.G., J. Chem. Phys., 82 (1985), 2418.

[70] Gutowski M., Chalasinski G., J. Chem. Phys., 98 (1993), 4728.

[71] TANaK H., PaWlus K., MarchewKa M.K., PIETRASZKo A., Spectrochim. Acta A, 118 (2014), 82.

[72] Fleming I. Frontier Orbitals and Organic Chemical Reactions, Wiley, London, 1976.

[73] Evecen M., Tanak H., Tinmaz F., Dege N., Ílhan İ.Ö., J. Mol. Struct., 1126 (2016), 117.

[74] Singh S.J., Pandey S.M., Indian J. Pure Ap. Phy., 12 (1974), 300.

[75] Tanak H., J. Phys. Chem. A, 115 (2011), 13865.

[76] Sajan D., Joe H., Jayakumar V.S., Zaleski J., J. Mol. Struct., 785 (2006), 43.

[77] Thanthiriwatte K.S., Silva DE N.K.M., J. Mol. Struc.-Theochem, 617 (2002), 169.

[78] Sun Y.X., HaO Q.L., WeI W.X., YU Z.X., LU L.D., WANG X., WANG Y.S., J. Mol. Struct., 929 (2009), 10.

[79] TANAK H., Int. J. Quantum Chem., 112 (2012), 2392. 
[80] Swarnalatha N., Gunasekaran S., Muthu S., [83] Tanak H., Mol. Phys., 112 (2014), 1553. NAGARAJAN M., Spectrochim. Acta A, 137 (2015), 721.

[81] Manimekalai A., Vijayalakshmi N., Spectrochim. Acta A, 136 (2015), 388.

[82] ZhaO P.S., XU J.M., Zhang W.G., Jian F.F., Received 2016-05-05 ZHANG L., Struct. Chem., 18 (2007), 993. 